\title{
Does the POA-SOA split matter for global CCN formation?
}

\author{
W. Trivitayanurak ${ }^{1, *}$ and P. J. Adams ${ }^{1,2}$ \\ ${ }^{1}$ Department of Civil and Environmental Engineering, Carnegie Mellon University, Pittsburgh, Pennsylvania, USA \\ ${ }^{2}$ Department of Engineering and Public Policy, Carnegie Mellon University, Pittsburgh, Pennsylvania, USA \\ *now at: Department of Highways, Ministry of Transport, Thailand \\ Correspondence to: P. J. Adams (petera@andrew.cmu.edu)
}

Received: 27 February 2013 - Published in Atmos. Chem. Phys. Discuss.: 22 April 2013

Revised: 3 November 2013 - Accepted: 8 December 2013 - Published: 28 January 2014

\begin{abstract}
A model of carbonaceous aerosols has been implemented in the TwO-Moment Aerosol Sectional (TOMAS) microphysics module in the GEOS-Chem chemical transport model (CTM), a model driven by assimilated meteorology. Inclusion of carbonaceous emissions alongside pre-existing treatments of sulfate and sea-salt aerosols increases the number of emitted primary aerosol particles by a factor of 2.5 and raises annual-average global cloud condensation nuclei at $0.2 \%$ supersaturation $(\mathrm{CCN}(0.2 \%))$ concentrations by a factor of two. Compared to the prior model without carbonaceous aerosols, this development improves the model prediction of condensation nuclei with dry diameter larger than $10 \mathrm{~nm}$ (CN10) number concentrations significantly from $-45 \%$ to $-7 \%$ bias when compared to long-term observations. Inclusion of carbonaceous particles also largely eliminates a tendency for the model to underpredict higher cloud condensation nuclei $(\mathrm{CCN})$ concentrations. Similar to other carbonaceous models, the model underpredicts organic carbon (OC) and elemental carbon (EC) mass concentrations by a factor of 2 when compared to EMEP and IMPROVE observations. Because primary organic aerosol (POA) and secondary organic aerosol (SOA) affect aerosol number size distributions via different microphysical processes, we assess the sensitivity of $\mathrm{CCN}$ production, for a fixed source of organic aerosol (OA) mass, to the assumed POA-SOA split in the model. For a fixed OA budget, we found that $\mathrm{CCN}(0.2 \%)$ decreases nearly everywhere as the model changes from a world dominated by POA emissions to one dominated by SOA condensation. POA is about twice as effective per unit mass at $\mathrm{CCN}$ production compared to SOA. Changing from a $100 \%$ POA scenario to a $100 \%$ SOA scenario, $\mathrm{CCN}(0.2 \%)$ concentrations in the lowest model layer decrease by about $20 \%$. In any scenario, carbonaceous aerosols contribute sig-
\end{abstract}

nificantly to global CCN. The SOA-POA split has a significant effect on global $\mathrm{CCN}$, and the microphysical implications of POA emissions versus SOA condensation appear to be at least as important as differences in chemical composition as expressed by the hygroscopicity of OA. These findings stress the need to better understand carbonaceous aerosols loadings, the global SOA budget, microphysical pathways of OA formation (emissions versus condensation) as well as chemical composition to improve climate modeling.

\section{Introduction}

Cloud condensation nuclei $(\mathrm{CCN})$ are the fraction of aerosol particles that activate to become cloud droplets. $\mathrm{CCN}$ concentrations and cloud processes play a critical role in determining the aerosol indirect radiative forcings, including increased cloud reflectivity and changes in cloud cover (Albrecht, 1989; Twomey, 1974), which are caused by anthropogenic increases in $\mathrm{CCN}$ levels. The Intergovernmental Panel on Climate Change (IPCC) has estimated the globally and annually averaged indirect aerosol radiative forcing (only the cloud brightness effect) to be between -1.8 and $-0.3 \mathrm{~W} \mathrm{~m}^{-2}$, compared to $+2.6 \mathrm{~W} \mathrm{~m}^{-2}$ by changes in longlived greenhouse gases, and has pointed out that the aerosol indirect forcing remains the dominant uncertainty in the net anthropogenic forcing estimate (IPCC, 2007). Improving the representation of $\mathrm{CCN}$ in global models, including mechanisms leading to their formation, enhances our understanding of $\mathrm{CCN}$ with the long-term goal of reducing uncertainty in aerosol indirect radiative forcing estimates. 
Organic aerosol (OA) is found to be a significant fraction of aerosol mass in the accumulation mode that accounts for most CCN (Hitzenberger et al., 1999). Many organics in aerosols have been shown to be CCN-active as OA contains a significant fraction of water-soluble organic carbon (WSOC) (Raymond and Pandis, 2002, 2003; Kerminen, 1997). Global modeling has also demonstrated the important role that OA plays in the global $\mathrm{CCN}$ budget (Pierce et al., 2007a; Merikanto et al., 2009).

Organic aerosol is composed of many compounds and has traditionally been categorized by the way it enters the atmosphere: primary emission or secondary production. OA that is emitted directly from fossil fuel and biomass combustion is termed "primary organic aerosol" (POA). In contrast, secondary organic aerosol (SOA) is formed in the atmosphere by condensation of low-volatility products from oxidation of volatile organic compounds. The relative contributions of POA and SOA to the total OA remains an open issue as different studies report wide ranges of estimates (Kanakidou et al., 2005; Hallquist et al., 2009). Traditionally, models have tended to predict a predominance of POA over SOA (Chung and Seinfeld, 2002; Kanakidou et al., 2005; Pun et al., 2003; Vutukuru et al., 2006), but measurement studies show striking evidence of SOA dominance observed at various locations, even in heavily urbanized locations (Zhang et al., 2005, 2007; de Gouw et al., 2005; Volkamer et al., 2006). Recent work has suggested that many global models are underestimating OA sources (Heald et al., 2010; Spracklen et al., 2011b) that appear to be SOA, and recent improvements in SOA modeling efforts have addressed this discrepancy (Jathar et al., 2011; Pye and Seinfeld, 2010). To complicate the matter even further, different measurement techniques result in different SOA/OA fractions, as was the case for the Pittsburgh Air Quality Study, for which SOA/OA values were estimated to be 35-73\% (Subramanian et al., 2007; Cabada et al., 2004; Shrivastava et al., 2007; Zhang et al., 2005). Therefore, there exists great uncertainty regarding the POASOA split.

Apart from obvious differences in the chemical composition of POA and SOA, they form via different microphysical pathways. POA emissions add to both aerosol mass and number concentrations, in both the ultrafine and CCN size ranges. Primary ultrafine particles compete for condensable gas, if available, and often grow to CCN (Pierce and Adams, 2007; Pierce et al., 2007b). Alternatively, these ultrafines undergo high coagulational scavenging loss, resulting in short atmospheric lifetimes. In contrast, condensation of SOA adds mass to existing particles without changing aerosol number concentrations. Condensation of SOA grows particles and can lead to $\mathrm{CCN}$ formation, but this depends on what size particle the SOA condenses onto (and, therefore, the preexisting aerosol size distribution) and whether the additional SOA results in a particle activating that would not otherwise activate. Previous work has demonstrated that uncertainty in the total SOA source has a significant impact on global CCN concentrations (Pierce and Adams, 2009).

Despite great uncertainty in the POA-SOA split, total organic aerosol sources, on the other hand, may be better quantified than those of POA or SOA individually. This leads to the question of how much, for a fixed total OA source, this POA-SOA split uncertainty translates into uncertainty in $\mathrm{CCN}$ predictions. This work will explore the sensitivity of CCN concentrations to different POA-SOA split assumptions and ask whether POA or SOA, per unit mass, is better at forming $\mathrm{CCN}$.

Additionally, this paper documents the implementation of carbonaceous aerosols in the highly size-resolved TwOMoment Aerosol Sectional (TOMAS) microphysics model (Adams and Seinfeld, 2002), which was integrated in the GEOS-Chem chemical transport model (CTM) (Bey et al., 2001) by Trivitayanurak et al. (2008). Previous work had developed a treatment of carbonaceous aerosols in TOMAS hosted by the GISS GCM II-prime (Pierce et al., 2007a). Using TOMAS hosted by GEOS-Chem, we present CCN predictions with and without carbonaceous aerosols to demonstrate the contribution of carbonaceous aerosols to $\mathrm{CCN}$ at the global scale. Comparison of model results to aerosol observations is performed to evaluate the model performance. Finally, we perform sensitivity simulations to test different POA-SOA split assumptions. Results from these simulations are used to answer the question whether POA or SOA is more effective at CCN formation.

Section 2 provides a model overview and describes the development of the model for carbonaceous aerosol, namely organic matter (OM) and black carbon (BC), in GEOS-CHEM with TOMAS. Section 3 contains model results, discusses the contribution of carbonaceous aerosols and presents a comparison with observations. Section 4 discusses the effects of the POA-SOA split on the CCN results. Finally, Sect. 5 concludes this study.

\section{Model description}

\subsection{Overview}

We represent carbonaceous aerosols in the GEOS-Chem global CTM with the Two-Moment Aerosol Sectional (TOMAS) microphysics model (Adams and Seinfeld, 2002). TOMAS tracks two independent moments, number and mass, of the aerosol size distribution for each size bin. Previous work implemented TOMAS in the GEOS-Chem host model as described in Trivitayanurak et al. (2008) and simulated sulfate and sea-salt aerosols.

The GEOS-Chem model is a 3-D tropospheric chemistry model driven by assimilated meteorological observations from the Goddard Earth Observing System (GEOS) of the NASA Global Modeling and Assimilation Office (GMAO) (Bey et al., 2001). We implemented our aerosol capabilities 
in GEOS-Chem version 7.04.11 (http://acmg.seas.harvard. edu/geos/geos_versions.html). The GEOS-3 GMAO meteorological fields are used to run the model with a horizontal resolution of $4^{\circ}$ latitude by $5^{\circ}$ longitude and a 30 level sigma-coordinate vertical grid between the surface and $0.01 \mathrm{hPa}$.

TOMAS is configured to track 30 size bins defined by dry particle mass, which span a size range of roughly $10 \mathrm{~nm}$ to $10 \mu \mathrm{m}$. In each bin, TOMAS tracks 8 quantities: sulfate mass, sea salt mass, mass of externally mixed $\mathrm{BC}$, mass of internally mixed $\mathrm{BC}$, hydrophobic $\mathrm{OM}$ mass, hydrophilic $\mathrm{OM}$ mass, mass of water and the number of aerosol particles in the bin. Besides the aerosol microphysics, GEOS-Chem simulates photochemistry with online oxidant, i.e., $\mathrm{OH}, \mathrm{H}_{2} \mathrm{O}_{2}$, $\mathrm{O}_{3}$, concentrations and also calculates sulfur chemistry, including DMS, MSA, $\mathrm{SO}_{2}$, and $\mathrm{H}_{2} \mathrm{SO}_{4}$. We use the binary nucleation scheme described in Adams and Seinfeld (2002), which calculates new particle formation based on a critical threshold value for rapid nucleation and available sulfuric acid concentrations (Wexler et al., 1994).

Advection is calculated every $30 \mathrm{~min}$ using the TPCORE algorithm (Lin and Rood, 1996). Size-dependent dry deposition of aerosols is modeled using the scheme of Zhang et al. (2001). Wet deposition includes in-cloud scavenging, below-cloud scavenging, and scavenging in convective updrafts. The large-scale clouds and convective clouds are assumed to experience maximum supersaturations of $0.19 \%$ and $0.75 \%$, respectively, for purposes of nucleation scavenging. The supersaturation at which particles in each size bin activate is determined from modified Köhler theory based on the current composition of that size bin and model grid cell (Seinfeld and Pandis, 1998; Hanel, 1976; Laaksonen et al., 1998; Raymond and Pandis, 2003). We neglect interstitial scavenging in clouds. First-order removal by belowcloud scavenging is calculated using size-dependent washout rate constants as in Adams and Seinfeld (2002). Convective updrafts remove aerosol by a first-order loss that affects only activated particles. A more comprehensive description of TOMAS implementation in the GEOS-Chem model can be found in Trivitayanurak et al. (2008).

\subsection{Improvements in particulate emissions}

Primary particulate emissions contribute significantly to aerosol number. "Primary" sulfate emissions, representing plume processing of power plant emissions, consist of an assumed fraction of total sulfur emission with a bimodal lognormal size distribution with number geometric mean diameters of 10 and $70 \mathrm{~nm}$ and standard deviations of 1.6 and 2.0, respectively (Adams and Seinfeld, 2002). In Trivitayanurak et al. (2008), particulate sulfate was prescribed to be $5 \%$ by mass of sulfur emission in Europe and $3 \%$ elsewhere. In this work, we reduce the fraction of "primary" particulate sulfate to be $1 \%$ everywhere following the development of Pierce and Adams (2009), who found that $3 \%$ of total sulfur consis- tently overpredicted the measured aerosol number in polluted regions even when carbonaceous aerosols were omitted.

Another improvement related to particulate emission is the development of a sub-grid coagulation parameterization based on Pierce et al. (2009). In this parameterization, primary particles undergo coagulation with the pre-existing aerosol size distribution in the source grid cell for $10 \mathrm{~h}$ to determine their "effective" regional emission and number size distributions; this helps the model to simulate appropriate regional background aerosol number concentrations.

\subsection{Carbonaceous aerosols implementation}

Size-resolved carbonaceous aerosols, namely organic matter $(\mathrm{OM})$ and black carbon (BC), are the new aerosol species implemented in this work. The model, therefore, tracks the $\mathrm{OM}$ mass concentration rather than the $\mathrm{OC}$ mass concentration, including the contributions of oxygen, hydrogen, and other elements to the aerosol mass. This implementation for TOMAS in the GEOS-Chem CTM largely follows the development of carbonaceous aerosols for TOMAS in GISS GCM-II' by Pierce et al. (2007a).

\subsubsection{Emissions}

Combustion sources of carbonaceous aerosols are categorized into fossil fuel, biofuel, and biomass burning. Note that oceanic emissions of organic aerosol are not considered here. Fossil fuel and biofuel emissions are taken from the Bond et al. (2004) global inventory. Seasonality of these emissions over North America follows Cooke et al. (1999) and Park et al. (2003) for fossil fuel and biofuel, respectively. Biomass burning emission is from the Global Fire Emissions Database version 2 (GFED2: on the web at http://www.falw. $\mathrm{vu/ \sim gwerf/GFED/GFED2/),} \mathrm{which} \mathrm{provides} \mathrm{monthly} \mathrm{vari-}$ ability as well as interannual variability from 1997 to 2004 (Giglio et al., 2006; van der Werf et al., 2006). Annual emission rates of $\mathrm{OM}$ and $\mathrm{BC}$ are summarized in Table 1. To convert from organic carbon (OC) mass normally reported in emission inventories to OM mass presented in our model, we assume a globally uniform and constant OM : OC ratio of 1.8 (El-Zanan et al., 2005; Yu et al., 2005; Zhang et al., 2005). Primary emissions of OM and BC in Table 1 total $55 \mathrm{Tg} \mathrm{yr}^{-1}$ and $7.7 \mathrm{Tg} \mathrm{yr}^{-1}$, respectively. After this work began, the Representative Concentration Pathways scenarios (Lamarque et al., 2011) were finalized but present very similar emissions for the year 2000: $35.9 \mathrm{Tg} \mathrm{OC} \mathrm{yr}^{-1}$ (or 64.6 $\mathrm{Tg} \mathrm{yr}^{-1}$ when converted to $\mathrm{OM}$ ) and $7.8 \mathrm{Tg} \mathrm{yr}^{-1}$ of $\mathrm{BC}$.

In general, size-resolved emissions inventories of primary particles are not available for global modeling, so assumptions about the size distributions are required. However, recent studies have emphasized the sensitivity of aerosol number and CCN predictions to either the number or size of primary particles (Pierce and Adams, 2009; Spracklen et al., 2011a; Reddington et al., 2011). For both OM and BC, fossil 
Table 1. Emission and production rates of $\mathrm{OM}$ and $\mathrm{BC}$ in the BASE scenario.

\begin{tabular}{lrrl}
\hline Sources & $\begin{array}{r}\text { OM sources } \\
\left(\mathrm{Tg} \mathrm{yr}^{-1}\right)\end{array}$ & $\begin{array}{r}\text { BC sources } \\
\left(\mathrm{Tg} \mathrm{yr}^{-1}\right)\end{array}$ & Reference \\
\hline Primary emissions: & & & \\
\hline Fossil fuel & 5 & 3.5 & Bond et al. (2004) \\
Biofuel & 13 & 1.6 & Bond et al. (2004) \\
Biomass burning & 37 & 2.6 & GFED2, Giglio et al. (2006) \\
\hline Secondary production: & & & \\
\hline Biogenic SOA & 18 & - & $10 \%$ of monoterpenes from \\
& & & MEGAN, Guenther et al. (2006)
\end{tabular}

fuel combustion is assumed to emit particles with a lognormal size distribution with number median diameter of $30 \mathrm{~nm}$ with a geometric standard deviation of 2; biofuel and biomass burning emissions are assumed to follow a lognormal distribution with a number median diameter of $100 \mathrm{~nm}$ and a geometric standard deviation of 2. Although subject to significant uncertainties, these values are similar to those assumed in other global modeling studies: median diameters of 30$60 \mathrm{~nm}$ for fossil fuel combustion and $80-150 \mathrm{~nm}$ for biofuel combustion and biomass burning (Reddington et al., 2011). Numerous studies have shown that the number distributions from fresh vehicle exhaust have median mode diameters of $30 \mathrm{~nm}$ or even smaller (Putaud et al., 2004; Van Dingenen et al., 2004; Ban-Weiss et al., 2010). Although other choices of primary size distributions are plausible, these are consistent with emissions measurements, other global models and, as will be shown later, result in predicted condensation nuclei with dry diameter larger than $10 \mathrm{~nm}$ (defined here as CN10) and $\mathrm{CCN}$ number concentrations that show little or no bias with respect to ambient observations.

\subsubsection{Secondary organic aerosol}

This work incorporates a simple treatment of SOA because, given rapidly changing knowledge of SOA and TOMAS's focus on aerosol microphysics, a simple treatment is more flexible and allows for easier sensitivity studies. In GEOS-Chem, SOA is produced by condensation of low-volatility products of the photooxidation of biogenic VOCs. Traditional global models that have included SOA produced from "traditional" anthropogenic organic precursors (i.e., single compounds with well-characterized smog chamber yields such as aromatics) have predicted that these make a small contribution (about 10\%) to global OA sources (Tsigaridis and Kanakidou, 2003; Farina et al., 2010), so they are not considered here. Potentially much larger sources of anthropogenic SOA from IVOC oxidation (Jathar et al., 2011; Pye and Seinfeld, 2010) are considered in the sensitivity studies (see Sect. 2.4). Following the assumption used by Park et al. (2003), we assume a $10 \%$ yield from monoterpenes emissions to produce
SOA in our model BASE case. Biogenic emissions in GEOSChem are calculated from the MEGAN model (Guenther et al., 2006). Annual-average SOA production from this calculation is $18.4 \mathrm{Tg} \mathrm{yr}^{-1}$, in agreement with previous estimates (Griffin et al., 1999).

In the model, SOA products are assumed to be produced immediately after emission of monoterpenes and are thereafter treated as non-volatile. Neglecting the time lag between emission of an SOA precursor and formation of SOA is a simplification used in much previous work, but it is worth considering some of its implications. Perhaps the most important is that the model SOA will be formed immediately in the boundary layer, where it is more subject to dry and wet deposition processes while, in reality, some SOA may form in the free troposphere and be longer-lived. For example, when transitioning from a simple SOA scheme similar to this one to a more physically based one, Zhang et al. (2012) found a $49 \%$ increase in OA burden, largely due to the long lifetime of SOA aloft. It is still unclear, however, whether missing sources of OA, probably SOA, occur mostly in the boundary layer or free troposphere. Measurements and box modeling suggest that substantial underprediction is already apparent in the polluted boundary layer (Volkamer et al., 2006). Model underestimates of OA in the free troposphere are severe in some instances but not observed in others (Heald et al., 2011, 2005). The simple approach used here and in other global models may underestimate the contribution of SOA to $\mathrm{CCN}$ to the extent that long-lived SOA is indeed formed in the free troposphere.

Previous SOA global modeling studies have adopted different choices regarding what constitutes the absorbing media for SOA partitioning into the aerosol phase. These choices include SOA itself (Kanakidou et al., 2000), entire condensed-phase organic (POA + SOA) (Pun et al., 2003; Chung and Seinfeld, 2002; Tsigaridis and Kanakidou, 2003; Kanakidou et al., 2000; Johnson et al., 2006), organic + inorganic aerosols (Tsigaridis and Kanakidou, 2003), and aqueous portion of the aerosol for the case of water soluble organic compounds (Seinfeld et al., 2001). Absorbing media still remains an uncertain factor. Regardless of what media 
constitutes the absorbing phase, which governs the thermodynamic equilibrium of SOA, there is still a question of kinetics and mass transfer that governs the size distribution of the condensed SOA. For simplicity here, we assume that the produced SOA irreversibly condenses onto the size distribution in proportion to the pre-existing aerosol surface area under ambient (hydrated) conditions, an assumption that has produced results in reasonable agreement with observations (Riipinen et al., 2011). We use total aerosol surface area from all species, both hydrophobic and hydrophilic, inorganic and organic, which is consistent with smog chamber studies in which SOA is observed to condense onto inorganic seed particles. This assumption also guarantees that SOA will reside primarily in the accumulation mode that contributes most aerosol surface area, consistent with ambient observations.

\subsubsection{Hygroscopicity, mixing state, $\mathrm{CCN}$ activation, and aging}

Carbonaceous aerosols are presented in the model as four categories: externally mixed $\mathrm{BC}$, internally mixed $\mathrm{BC}$, hydrophobic OM, and hydrophilic OM. Aerosols are divided into two populations for the purpose of $\mathrm{CCN}$ activation calculations. The first population is solely the externally mixed $\mathrm{BC}$ or "pure BC", and the other population is an internal mixture of all other aerosols, including mixed $\mathrm{BC}$, hydrophilic $\mathrm{OM}$, hydrophobic OM, sulfate and sea salt. The externally mixed BC population does not activate and, therefore, is not subject to nucleation scavenging. $\mathrm{CCN}$ activation for the mixed aerosol population is calculated using modified Köhler theory (Pierce et al., 2007a), which allows for calculation of the activation diameter of particles containing various soluble and insoluble species. We ignore changes in surface tension by surfactant effects of the organic aerosols. BC mass is insoluble in both populations, but the mixed BC may occur in activated particles and, therefore, be subject to nucleation scavenging. Hydrophobic and hydrophilic OM are assumed to be insoluble and completely soluble, respectively. Pure hydrophilic $\mathrm{OM}$ is assumed to have a critical dry diameter for activation of $140 \mathrm{~nm}$ at $0.2 \%$ supersaturation, but activation calculations are performed with the composition of the "internally mixed" population as discussed above. This critical diameter is similar to pinonic acid and adipic acid (Raymond and Pandis, 2002). In terms of the $\kappa$ parameter (Petters and Kreidenweis, 2007), hydrophilic OM has $\kappa=0.18$ and hydrophobic OM has $\kappa=0$ at $273 \mathrm{~K}$. The assumed density of hydrophilic $\mathrm{OM}$ is $1.4 \mathrm{~g} \mathrm{~cm}^{-3}$ and hydrophobic OM is $1.8 \mathrm{~g} \mathrm{~cm}^{-3}$. Kappa values inferred for ambient organics, laboratory SOA, and many single organic compounds found in $\mathrm{OA}$ are quite consistent with these values, mostly falling in the range of 0.1-0.3 (Suda et al., 2012; Petters and Kreidenweis, 2007; Gunthe et al., 2009).

Our emissions of $\mathrm{OM}$ and $\mathrm{BC}$ use hygroscopicity and mixing state assumptions following those originally made by Cooke et al. (1999) for fossil fuel sources and subse-
Table 2. Overview of simulations.

\begin{tabular}{lrrr}
\hline Name & $\begin{array}{r}\text { BC Emission } \\
\text { Rate }\left(\mathrm{Tg} \mathrm{yr}^{-1}\right)\end{array}$ & $\begin{array}{r}\text { POA Emission } \\
\text { Rate }\left(\mathrm{Tg} \mathrm{yr}^{-1}\right)\end{array}$ & $\begin{array}{r}\text { SOA Production } \\
\text { Rate }\left(\mathrm{Tg} \mathrm{yr}^{-1}\right)\end{array}$ \\
\hline NOCARB & None & None & None \\
BASE & 8 & 55 & 18 \\
0SOA & 8 & 55 & 0 \\
10SOA & 8 & 50 & 6 \\
50SOA & 8 & 28 & 28 \\
90SOA & 8 & 6 & 50 \\
100SOA & 8 & 0 & 55 \\
\hline
\end{tabular}

quently applied to all source categories by most subsequent global aerosol modeling. Very few measurements have been made to test these assumptions. Fifty percent of OM emissions are assumed to be hydrophobic and the other $50 \%$ are hydrophilic. As for BC, $80 \%$ is assumed to be emitted as pure BC and $20 \%$ as mixed BC. Secondary organic aerosol formed in the model is assumed to be completely hydrophilic. SOA water solubility and its relation to WSOC have been discussed in a number of studies (Saxena and Hildemann, 1996; Kumagai et al., 2009; Kondo et al., 2007).

Aging of carbonaceous particles includes the conversion of hydrophobic $\mathrm{OM}$ to hydrophilic $\mathrm{OM}$ and the conversion of pure $\mathrm{BC}$ to mixed $\mathrm{BC}$ via mixing processes. Both processes are modeled in our work using an e-folding time of 1.15 days. This conversion timescale affects the wet deposition lifetime of carbonaceous aerosol but remains uncertain (Cooke et al., 1999; Koch et al., 1999; Park et al., 2005). Park et al. (2005) explored a range of aging timescales in the GEOS-CHEM model and found that timescales of 0 2 days were consistent with TRACE-P observations of BC scavenging. The corresponding range for the global $\mathrm{BC}$ burden was $0.11 \pm 0.03 \mathrm{Tg}$ C. Because the aging timescale is relatively short, hydrophilic OM tends to dominate the organic aerosol composition. For the same reason, internally mixed EC constitutes $85 \%$ of the elemental carbon (EC) burden. Although the treatment of aging is crude, this result may be seen as broadly consistent with ambient data that show a predominance of oxygenated organic aerosol (OOA) over hydrocarbon-like organic aerosol (HOA) (Zhang et al., 2007) as well as data that show that typically $60 \%$ of OA is water soluble (Kerminen, 1997).

\subsection{Overview of simulations}

Table 2 summarizes the base case and different sensitivity simulations used in this work. All simulations are carried out for 14 months starting from 1 November 2000, with the first two months discarded from the analysis to allow for model initialization. Each simulation differs in the aerosol species included or the treatment of organic aerosol sources.

The NOCARB simulation has only sulfate and sea salt aerosols. It should be noted that the NOCARB simulation is different from the results presented in Trivitayanurak 
et al. (2008) due to the recent developments discussed in Sect. 2.3.1 that lower the predicted number concentrations. The BASE simulation includes sulfate, sea salt, BC and OM, with SOA production calculated as $10 \%$ of monoterpene emissions.

In the POA-SOA split experiments, which include the OSOA, 10SOA, 50SOA, 90SOA, and 100SOA simulations, the only change from the BASE simulation is that we omit the SOA production from monoterpenes. Instead, we take the current POA emission rates to be the total OM source and artificially vary the contribution of SOA production to the total $\mathrm{OM}$ by deducting $f$ percent of mass from the POA source and condensing it as SOA. The 5 experimental simulations have SOA/OA source ratios of $0 \%, 10 \%, 50 \%, 90 \%$, and $100 \%$. The reason for the wide range of scenarios is to include the full range from traditional OA models that are dominated by POA to AMS measurements that suggest a world dominated by OOA and SOA. Given the status of scientific knowledge and current representation of OA processes in the model, these scenarios capture some, but not all, of the differences between POA and SOA. For example, the fact that POA emissions contribute a large number of particles to the atmosphere (Spracklen et al., 2011a) whereas SOA formation simply grows existing particles is represented; however, the assumption of instantaneous SOA formation (see Sect. 2.3.2) does not capture the potentially different SOA lifetime if it is largely formed in the free troposphere. Moreover, the likelihood that POA emissions shrink by evaporation and then regrow by SOA formation (Hallquist et al., 2009; Robinson et al., 2007) is not yet represented in the microphysics used here. Therefore, the sensitivity experiments should be viewed as partly idealized representations of the differences caused by different POA and SOA formation pathways.

As we increase the SOA contribution in these experiments, the hydrophobic-hydrophilic split is shifted since SOA is assumed to form as soluble species, unlike POA emission that also has the insoluble fraction. However, due to relatively fast aging assumed in the model, hydrophilic OM dominates relatively quickly and thus the composition of the OSOA and 100SOA cases are not dramatically different. Therefore, the major differences between the simulations result from different aerosol size distributions stemming from the different microphysical pathways that form POA and SOA. Influence of composition on global $\mathrm{CCN}$ will be discussed again in Sect. 4.

\section{Results}

\subsection{Global aerosol distributions}

Figure 1a and $\mathrm{b}$ show the annual-average predicted aerosol number $(\mathrm{CN} 10)$ and $\mathrm{CCN}(0.2 \%)$ concentrations for the model surface layer from the BASE simulation. $\mathrm{CN} 10$ is defined as condensation nuclei with dry diameter larger than
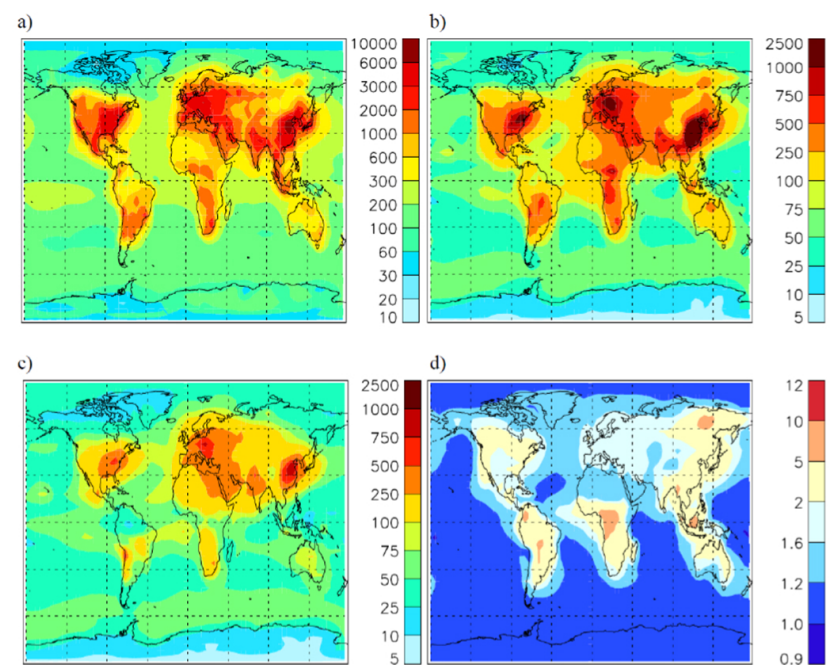

Fig. 1. Annual-average number concentrations in the surface layer $\left(\mathrm{cm}^{-3}\right.$ at $\left.298 \mathrm{~K}, 1 \mathrm{~atm}\right)$ for (a) CN10 from the BASE simulation; (b) $\mathrm{CCN}(0.2 \%)$ from the BASE simulation; (c) $\operatorname{CCN}(0.2 \%)$ from the NOCARB simulation, and (d) ratios of predicted annualaverage $\mathrm{CCN}(0.2 \%)$ concentrations in the surface layer as $(\mathrm{CCN}$ BASE)/(CCN NOCARB)

$10 \mathrm{~nm}$ and $\mathrm{CCN}(0.2 \%)$ is cloud condensation nuclei at $0.2 \%$ supersaturation; all concentrations are $\mathrm{cm}^{-3}$ at $298 \mathrm{~K}$ and $1 \mathrm{~atm}$. The predictions follow expected features with higher number concentrations over land than ocean. Predicted CN10 concentrations reach $10000 \mathrm{~cm}^{-3}$ in the most polluted areas. Continental CN10 concentrations outside the most polluted regions range from 300 to $3000 \mathrm{~cm}^{-3}$. Marine boundary layer CN10 concentrations are $60-300 \mathrm{~cm}^{-3}$ (Andreae et al., 1995; Clarke et al., 1987; Covert et al., 1996; Fitzgerald, 1991; Pandis et al., 1995; Raes et al., 2000).

$\mathrm{CCN}(0.2 \%)$ predictions at the lowest model layer follow similar trends as $\mathrm{CN} 10$ predictions. $\mathrm{CCN}(0.2 \%)$ concentrations over the most polluted regions exceed $1000 \mathrm{~cm}^{-3}$. $\mathrm{CCN}(0.2 \%)$ concentrations typically range from 100 to $1000 \mathrm{~cm}^{-3}$ over the continents, while they range from 25 to $100 \mathrm{~cm}^{-3}$ over oceans, in agreement with observations (Andreae et al., 1995).

\subsection{Contribution of carbonaceous aerosols to $\mathrm{CN}$ and CCN}

Figure $1 \mathrm{c}$ and $\mathrm{d}$ show the annual-average model surface layer $\operatorname{CCN}(0.2 \%)$ concentrations of the NOCARB simulation and the $\operatorname{CCN}(0.2 \%)$ enhancement ratios due to the additional carbonaceous aerosols in the BASE simulation. $\mathrm{CCN}(0.2 \%)$ concentrations increase over all continental and near-continental regions by $\sim 20 \%$ over polluted marine areas up to a tenfold increase in the biomass burning source regions. The increased $\mathrm{CCN}(0.2 \%)$ concentrations are found throughout the troposphere but are strongest within the Northern Hemisphere where the majority of combustion 

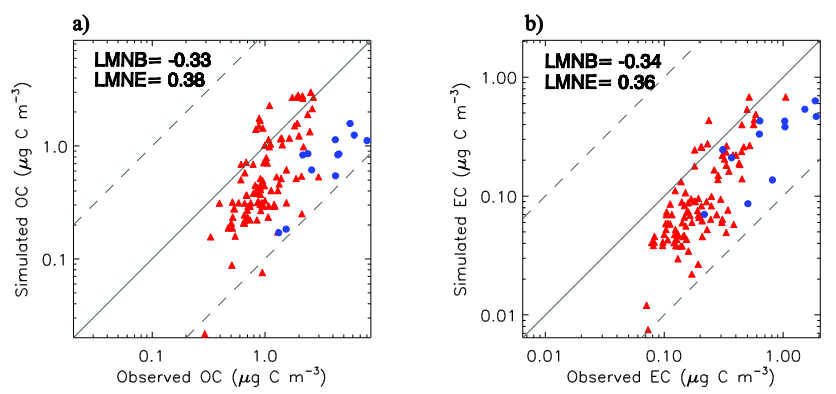

Fig. 2. Comparison of predicted concentrations with observed concentrations ( $\mu \mathrm{g} \mathrm{C} \mathrm{m}^{-3}$ at $298 \mathrm{~K}$ and $1 \mathrm{~atm}$ ) for (a) organic carbon (OC) and (b) elemental carbon (EC). Solid lines show a $1: 1$ ratio and dashed lines show ratios of $10: 1$ and $1: 10$. Blue circles refer to observations from the EMEP network. Red triangles refer to observations from the IMPROVE network. Log-mean normalized bias (LMNB) and log-mean normalized error (LMNE) are listed in each panel.

sources are located. At the $300 \mathrm{hPa}$ level, the $\mathrm{CCN}(0.2 \%)$ increase is spatially homogenous within hemispheres and around $20 \%$ over the Southern Hemisphere and a $~ 60 \%$ increase over the Northern Hemisphere (not shown).

Table 3 presents globally and annually averaged aerosol number budget calculations for the NOCARB and BASE simulations. For these budget calculations, the burden includes only aerosols below the annual mean tropopause level. For ease of interpretation, source, growth, and sink terms are normalized by a fixed tropospheric volume assuming a $12 \mathrm{~km}$ tropopause. The budgets are categorized by size modes as ultrafine (UF), defined as particles with dry diameter below $80 \mathrm{~nm}$, and CCN mode, defined as those with dry diameter above $80 \mathrm{~nm}$. Note that we categorize budget components as source, microphysical growth, and sink. Microphysical growth process terms in Table 3, including condensation of sulfuric acid, condensation of SOA, and aqueous production of sulfate by cloud processing, denote the rates at which particles cross the $80 \mathrm{~nm}$ size threshold chosen here. Coagulation can be either a sink for small particles or a microphysical growth term for larger particles. Carbonaceous aerosol increases annual-average primary emissions from $14 \mathrm{~cm}^{-3} \mathrm{day}^{-1}$ to $35 \mathrm{~cm}^{-3}$ day $^{-1}$, almost all in the ultrafine mode. This increase in emissions raises the contribution of primary emissions to UF sources from $14 \%$ to $26 \%$, the rest being nucleation. Among processes responsible for $\mathrm{CCN}$ production, increased emissions in $\mathrm{CCN}$ mode enlarge the contribution of primary emission relative to microphysical growth from $16 \%$ to $31 \%$. SOA condensation accounts for only $5 \%$ of $\mathrm{CCN}$ sources in the BASE case, but it should be remembered that SOA production in the BASE case is only $18 \mathrm{Tg} \mathrm{yr}^{-1}$. The global UF number burden increases by $15 \%$ while CCN numbers double. Primary carbonaceous aerosol plays important roles in global CCN increase, both by direct emission at $\mathrm{CCN}$ sizes as well as by
UF emissions that subsequently grow to $\mathrm{CCN}$ sizes by condensation. These latter processes can be seen in Table 3 in which the BASE simulation has higher $\mathrm{CCN}$ formation rates from $\mathrm{SO}_{4}$ condensation and aqueous oxidation of sulfate despite the fact that sulfur emissions are the same in both simulations; emissions of UF carbonaceous aerosols increase the amount of sulfate condensing onto smaller particles and the number of UF particles that grow to $\mathrm{CCN}$ sizes. Lifetimes of UF- and CCN-mode aerosols change slightly from NOCARB to BASE simulations with similar contributions of each sink, e.g., coagulation being the largest sink for UFmode particles, wet deposition as the major sink of $\mathrm{CCN}$ mode.

\subsection{Carbonaceous model evaluation}

\subsubsection{Carbonaceous aerosol mass}

We compare the predicted carbonaceous aerosol mass concentrations with measurements from the European Monitoring and Evaluation Program (EMEP) (http://www.emep.int/ index.html) and with measurements from the Interagency Monitoring of Protected Visual Environments (IMPROVE) network (IMPROVE, 1995). For EMEP, all measurements were made as part of the OC/EC campaign during 2002 and 2003. The IMPROVE data set represents measurements taken during 2000 and 2001. For both networks, we compare our model predictions to measurements of EC as opposed to $\mathrm{BC}$, which are not precisely equivalent (Bond and Bergstrom, 2006), but the relationship between BC and EC is still problematic. Noting this issue and potential uncertainties it entails, we assume that our model predictions of BC are equivalent to $\mathrm{EC}$ and can be compared to $\mathrm{EC}$ measurements on a $1: 1$ basis. In fact, BC emissions inventories have sometimes used EC measurements as equivalent to $\mathrm{BC}$, albeit with higher assigned uncertainties (Bond et al., 2004). We compare our model-predicted OM concentrations to OC measurements by dividing by a uniform OM : OC ratio of 1.8 .

Figure 2 summarizes the annual-average comparison of $\mathrm{OC}$ and EC concentrations predicted at the surface level in the BASE simulation with the measurements from both networks. The model underpredicts OC and EC mass somewhat with log-mean normalized bias (LMNB) values of -0.33 and -0.34 for OC and EC, respectively. These LMNB values correspond to underpredictions of a factor of $\sim 2$ on average. This degree of underprediction is not surprising for a model with a "traditional" (e.g., SOA from biogenic precursors only) treatment of organic aerosol. For example, similar global models have exhibited underpredictions of a factor of 2 to 10 (Chung and Seinfeld, 2002; Park et al., 2003; Liousse et al., 1996; Tsigaridis and Kanakidou, 2003; de Gouw et al., 2005; Volkamer et al., 2006; Heald et al., 2005, 2006) although some models have had only minor biases of $\sim 20 \%$ (Park et al., 2006). Our model agreement is better with the IMPROVE sites than with the EMEP sites. Moreover, our 
Table 3. Global annual-average aerosol number budgets comparing NOCARB and BASE simulations. Size mode for ultrafine (UF) covers $0.01-0.08 \mu \mathrm{m}$ and CCN mode covers $0.08-10 \mu \mathrm{m}$.

\begin{tabular}{|c|c|c|c|c|}
\hline \multirow[b]{2}{*}{ Size mode } & \multicolumn{2}{|c|}{ NOCARB } & \multicolumn{2}{|c|}{ BASE } \\
\hline & UF & $\mathrm{CCN}$ & UF & $\mathrm{CCN}$ \\
\hline \multicolumn{5}{|c|}{ Sources $\left(\mathrm{cm}^{-3}\right.$ day $\left.^{-1}\right)$} \\
\hline Primary emissions & 13 & 1.2 & 31 & 4 \\
\hline Nucleation $\left(\mathrm{J}_{10}\right)$ & 78 & 0 & 89 & 0 \\
\hline Total & 91 & 1.2 & 120 & 4 \\
\hline \multicolumn{5}{|c|}{ Microphysical growth $\left(\mathrm{cm}^{-3} \mathrm{day}^{-1}\right)$} \\
\hline $\mathrm{SO}_{4}$ condensation & -2.1 & 2.1 & -2.5 & 2.5 \\
\hline Aqueous oxidation & -4.2 & 4.2 & -5.8 & 5.8 \\
\hline SOA condensation & - & - & -0.6 & 0.6 \\
\hline Total & -6.3 & 6.3 & -8.9 & 8.9 \\
\hline \multicolumn{5}{|l|}{ Sinks $\left(\mathrm{cm}^{-3}\right.$ day $\left.^{-1}\right)$} \\
\hline Dry deposition & 8.8 & 1.2 & 15 & 2.6 \\
\hline Wet deposition & 6.7 & 6.2 & 8.5 & 10 \\
\hline Coagulation & 69 & 0 & 87 & 0.6 \\
\hline Total & 85 & 7.4 & 111 & 13 \\
\hline Burden $\left(\mathrm{cm}^{-3}\right)$ & 750 & 29 & 871 & 61 \\
\hline Lifetime (days) & 9 & 4 & 8 & 5 \\
\hline
\end{tabular}

model tends to predict OC mass concentrations with little bias against the more polluted sites, but with a pronounced tendency to underpredict at cleaner sites.

\subsubsection{Aerosol number and CCN concentrations}

We compare the annual-average predicted CN10 concentrations from the BASE model in the surface layer with longterm CN10 observations shown in Table 4. The data is limited to sites outside of urban areas with a minimum sample of about one year. The sites included are part of a European network of sites presented in Van Dingenen et al. (2004), the Global Monitoring Division (GMD) of the Earth Systems Research Laboratory (Schnell, 2003) (http://www.esrl. noaa.gov/gmd/), and the Thompson Farm site of AIRMAP (http://airmap.unh.edu/). Locations of the $\mathrm{CN}$ observation sites are shown in Fig. 3a.

Figure $4 \mathrm{a}$ and $\mathrm{b}$ presents the comparison of simulated CN10 against the observed $\mathrm{CN} 10$ at various sites for the NOCARB and BASE simulations. Types of observational sites are color-coded in the data points as blue for European sites, red for North American sites, green for remote sites, and cyan for free tropospheric sites. Before the implementation of carbonaceous aerosols, the model underpredicted aerosol number concentrations at most locations in the NOCARB simulation and most especially in more polluted locations. Without primary emissions of carbonaceous aerosols, model predictions had an LMNB of -0.26 , meaning that the model underpredicted on average by $\sim 45 \%$ $\left(10^{-0.26}=0.55\right)$. The log-mean normalized error (LMNE) was 0.37 , which translates to an overall absolute error of a factor of $10^{0.37}=2.3$. With carbonaceous aerosols, model predictions compare much better with observations, resulting in an LMNB of -0.032 ( $-7 \%$ bias). The LMNE is calculated to be 0.19 , which equals an overall absolute error of a factor of about $50 \%$. The model, therefore, is able to capture nearly two orders of magnitude variability in aerosol number concentrations with little bias and modest errors. Introduction of carbonaceous aerosol markedly improved model predictions for European and North American sites while having minor impacts on the remote and free troposphere locations.

We have also compared our predicted $\mathrm{CCN}$ concentrations (NOCARB and BASE scenarios) against the compilation of measurements made by Spracklen et al. (2011a), which cover a range of supersaturations. The locations of those $\mathrm{CCN}$ measurements are shown in Figure $3 \mathrm{~b}$. The results of the comparison are presented in Fig. $4 \mathrm{c}$ and $\mathrm{d}$ and are consistent with the CN10 comparisons just discussed. Without carbonaceous emissions, the model tends to underpredict $\mathrm{CCN}$ concentrations, having a LMNB of -0.42 , which corresponds to an underprediction of a factor of 2.6 on average. Figure $4 \mathrm{c}$ shows that, without carbonaceous aerosols, the discrepancies are most severe (nearly an order of magnitude) at higher $\mathrm{CCN}$ concentrations, corresponding to polluted 

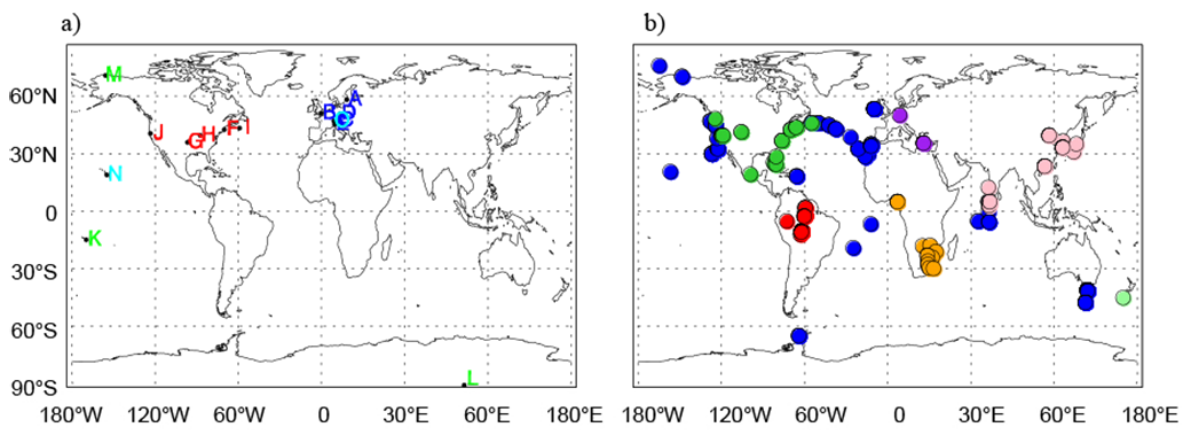

Fig. 3. Locations of aerosol number concentration measurements used for model evaluation of (a) CN10 and (b) CCN. For CN10, letters correspond to those listed in Table 4. Dark blue letters denote European boundary layer, red letters denote polluted North American boundary layer, green is for remote boundary layer, and cyan denotes free troposphere. For CCN, colors denote locations; blue symbols refer to marine boundary layer sites, green symbols are North American sites, red symbols are Central and South American sites, purple symbols are European sites, orange symbols are African sites, pink symbols are Asian sites, and pale green symbols are New Zealand sites.

Table 4. Locations of number concentration measurements used for comparison.

\begin{tabular}{|c|c|c|c|c|c|c|c|c|}
\hline & Location & Region & Reference & Time & Long. & Lat. & $\begin{array}{c}\text { Elevation } \\
(\mathrm{m})\end{array}$ & $\begin{array}{r}\mathrm{CN} 10 \\
\left(\mathrm{~cm}^{-3}\right)\end{array}$ \\
\hline A & Aspvereten, Sweden & Europe & Van Dingenen et al. (2004) & Jan 2001-Dec 2001 & $17.4^{\circ} \mathrm{E}$ & $58.8^{\circ} \mathrm{N}$ & 20 & 2000 \\
\hline $\mathrm{B}$ & Harwell, United Kingdom & Europe & Van Dingenen et al. (2004) & May $1998-$ Nov 2000 & $1.3^{\circ} \mathrm{W}$ & $51.6^{\circ} \mathrm{N}$ & 125 & 3000 \\
\hline $\mathrm{C}$ & Hohenpeissenberg, Germany & Europe & Van Dingenen et al. (2004) & Apr 1998-Aug 2000 & $11^{\circ} \mathrm{E}$ & $47.8^{\circ} \mathrm{N}$ & 988 & 2500 \\
\hline $\mathrm{D}$ & Melpitz, Germany & Europe & Van Dingenen et al. (2004) & Dec 1996-Nov 1997 & $12.9^{\circ} \mathrm{E}$ & $51.5^{\circ} \mathrm{N}$ & 86 & 5600 \\
\hline $\mathrm{E}$ & Ispra, Italy & Europe & Van Dingenen et al. (2004) & Feb 2000-Dec 2000 & $8.6^{\circ} \mathrm{E}$ & $45.8^{\circ} \mathrm{N}$ & 209 & 9000 \\
\hline $\mathrm{F}$ & Thompson Farm, New Hamshire, US & North America & http://airmap.unh.edu & $2001-2005$ & $71^{\circ} \mathrm{W}$ & $43.1^{\circ} \mathrm{N}$ & 75 & 7250 \\
\hline G & Lamont, Oklahoma, US & North America & http://www.cmdl.noaa.gov/aero/data/ & $1996-2004$ & $97.5^{\circ} \mathrm{W}$ & $36.5^{\circ} \mathrm{N}$ & 318 & 5200 \\
\hline $\mathrm{H}$ & Bondville, Illinois, US & North America & http://www.cmdl.noaa.gov/aero/data/ & 1994-2005 & $88.3^{\circ} \mathrm{W}$ & $40.1^{\circ} \mathrm{N}$ & 230 & 3700 \\
\hline I & Sable Island, Nova Scotia, Canada & North America & http://www.cmdl.noaa.gov/aero/data/ & $1992-1999$ & $60^{\circ} \mathrm{W}$ & $43.9^{\circ} \mathrm{N}$ & 5 & 850 \\
\hline $\mathrm{J}$ & Trinidad Head, California, US & North America & http://www.cmdl.noaa.gov/aero/data/ & $2002-2005$ & $124.2^{\circ} \mathrm{W}$ & $41.1^{\circ} \mathrm{N}$ & 107 & 590 \\
\hline K & American Samoa & Remote & http://www.cmdl.noaa.gov/aero/data/ & $1995-2005$ & $170.5^{\circ} \mathrm{W}$ & $14.2^{\circ} \mathrm{S}$ & 42 & 220 \\
\hline $\mathrm{L}$ & South Pole & Remote & http://www.cmdl.noaa.gov/aero/data/ & 1995-2005 & $102^{\circ} \mathrm{E}$ & $90^{\circ} \mathrm{S}$ & 2810 & 100 \\
\hline M & Point Barrow, Alaska, US & Remote & http://www.cmdl.noaa.gov/aero/data/ & $1995-2005$ & $156.6^{\circ} \mathrm{W}$ & $71.3^{\circ} \mathrm{N}$ & 11 & 110 \\
\hline $\mathrm{N}$ & Mauna Loa, Hawaii, US & Free Troposphere & http://www.cmdl.noaa.gov/aero/data/ & $1995-2005$ & $155.6^{\circ} \mathrm{W}$ & $19.5^{\circ} \mathrm{N}$ & 3397 & 330 \\
\hline $\mathrm{O}$ & Jungfraujoch, Switzerland & Free Troposphere & Van Dingenen et al. (2004) & Jun 1997-May 1998 & $8^{\circ} \mathrm{E}$ & $47.6^{\circ} \mathrm{N}$ & 3580 & 525 \\
\hline
\end{tabular}

environments and/or higher supersaturations in the $\mathrm{CCN}$ instrument. Both of these trends are consistent with missing carbonaceous aerosol. In contrast, the introduction of carbonaceous aerosol to the model (Fig. 4d) greatly improves predictions. A small bias towards underpredictions of about $\sim 20 \%$ (LMNB of -0.10 ) persists, but the model demonstrates much better predictions at the higher CCN concentrations that are problematic without carbonaceous aerosols. Model errors are significant, however, and the LMNE of 0.37 corresponds to errors greater than a factor of two. The fact that the model has larger errors when compared to $\mathrm{CCN}$ measurements than $\mathrm{CN} 10$ measurements may be partly attributable to the fact that $\mathrm{CCN}$ measurements, especially the control of small supersaturations, are more difficult. Spracklen et al. (2011a) also found that the introduction of carbonaceous emissions corrected a similar bias in their model's CCN predictions, suggesting that primary carbonaceous particles are an important source of $\mathrm{CCN}$ in polluted regions.

Overall, these comparisons suggest that our model has approximately the correct number of primary carbonaceous particles of both ultrafine and CCN sizes but insufficient carbonaceous mass at the polluted boundary layer sites measured by the EMEP and IMPROVE networks. Because the ultimate contribution of carbonaceous aerosol to $\mathrm{CCN}$ depends on both number and (soluble) mass, the model's good $\mathrm{CCN}$ predictions may result from some compensating errors. Nevertheless, the comparison demonstrates skill similar to other global models.

\section{Effects of POA-SOA split on CCN}

To explore the effect of varying the POA-SOA split on global $\mathrm{CCN}(0.2 \%)$ predictions, we conducted 5 POA-SOA split sensitivity runs as described in Sect. 2.4, ranging from treating OA as pure POA (OSOA simulation) to all OA as SOA (100SOA simulation). These runs suggest what the tropospheric aerosol would look like in a POA-dominant world versus a SOA-dominant world. As the model has a relatively fast aging (hydrophobic-hydrophilic conversion), the composition of the OM in all scenarios is similar and mostly dominated by hydrophilic OM. Therefore, these sensitivity 

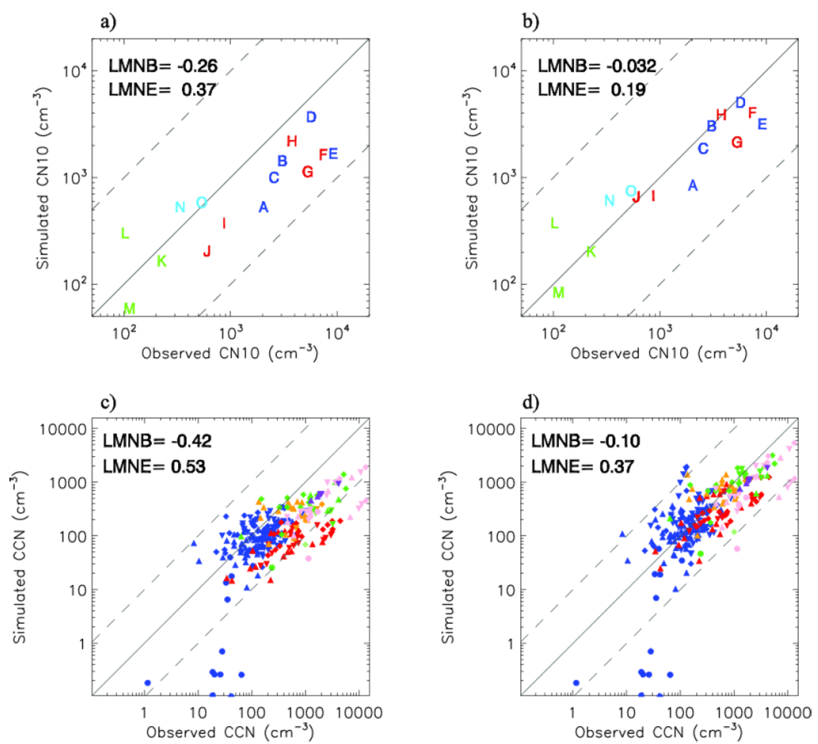

Fig. 4. Comparison of predicted and observed number concentrations with and without carbonaceous aerosols: predicted CN10 concentrations $\left(\mathrm{cm}^{-3}\right.$ at $298 \mathrm{~K}$ and $\left.1 \mathrm{~atm}\right)$ compared to observations for (a) NOCARB and (b) BASE simulations; predicted CCN concentrations $\left(\mathrm{cm}^{-3}\right.$ at $298 \mathrm{~K}$ and $\left.1 \mathrm{~atm}\right)$ compared to observations for (c) NOCARB and (d) BASE simulations. Solid lines show a $1: 1$ ratio, and dashed lines show ratios of $10: 1$ and $1: 10$. For the top panels, the letters refer to the locations presented in Table 4. Blue letters refer to European sites. Red letters refer to North Americans sites. Green letters refer to remote sites. Cyan letters refer to free tropospheric sites. Lower panels show CCN binned by supersaturations $(s)$ : circles for $s<0.1 \%$, upward triangles for $0.1 \% \leq s<0.4 \%$, downward triangles for $0.4 \% \leq s \leq 0.8 \%$, and diamonds for $s>0.8 \%$. Colors denote locations: blue symbols refer to marine boundary layer sites, green symbols are North American sites, red symbols are Central and South American sites, purple symbols are European sites, orange symbols are African sites, pink symbols are Asian sites, and pale green symbols are New Zealand sites. Log-mean normalized bias (LMNB) and log-mean normalized error (LMNE) are listed in each panel.

results highlight the microphysical effects of POA versus SOA on CCN formation as reflected in the aerosol number distributions. $\mathrm{CCN}(0.2 \%)$ concentrations in the model surface layer are the focus here because boundary layer $\mathrm{CCN}$ are thought to be most important to altering stratiform clouds, which contribute most to global albedo.

\subsection{Effect on global CCN distribution}

Figure 5 presents annual-average $\mathrm{CCN}(0.2 \%)$ concentrations in the surface layer predicted from the 10SOA simulation and their changes in the 90SOA simulation, which are presented as ratios of $\mathrm{CCN}(0.2 \%)$ concentrations in the 90SOA to 10SOA simulations. In general, the result of increasing SOA in the POA-SOA split is a reduction in $\mathrm{CCN}(0.2 \%)$ by $10-30 \%$ away from biomass burning source regions and up to $80 \%$ decreases over the biomass burning source regions. Over the oceans, where carbonaceous aerosols make a small contribution as shown in Fig. 1d, the changes in $\mathrm{CCN}(0.2 \%)$ are less than $10 \%$, mostly decreases, due to differences in background aerosol concentrations in the two simulations.

There are three direct impacts on the $\mathrm{CCN}(0.2 \%)$ population when we increase SOA in the split: (1) direct decrease of $\mathrm{CCN}(0.2 \%)$ by reducing $\mathrm{CCN}$-mode primary emissions and (2) reduction of UF-mode primary emission that might grow to $\mathrm{CCN}$, and (3) additional condensation of SOA that may or may not contribute to $\mathrm{CCN}$ production, depending on what size of pre-existing particles SOA condenses onto. These direct impacts may induce other feedbacks including changes in nucleation and deposition rates. To contribute to $\mathrm{CCN}(0.2 \%)$ formation, SOA must condense onto UF-mode particles. The overall tendency to decrease CCN when shifting POA to SOA indicates that the first two effects combined are stronger than the third and highlights the importance of primary particles to the global CCN budget (Adams and Seinfeld, 2003).

Comparing the 90SOA with 10SOA simulations, major $\mathrm{CCN}(0.2 \%)$ reductions are localized in biomass burning source regions, and more modest decreases occur in the fossil fuel combustion source regions such as North America or East Asia. This is largely because ultrafine sulfate aerosols (resulting either from assumed in-plume nucleation events or regional-scale nucleation events) are available in polluted source regions to compensate for the reduced UF-mode POA emission, whereas primary carbonaceous particles are the dominant source of aerosol numbers in biomass burning regions. This will be discussed more in the next section.

\subsection{Effect on size distributions}

Figure $6 \mathrm{a}$ and $\mathrm{b}$ show number size distributions from the 10SOA and 90SOA simulations for Congo $\left(12.5-32.5^{\circ} \mathrm{E}\right.$ and $0-8^{\circ} \mathrm{S}$ ) biomass burning region and a North American $\left(107.5-112.5^{\circ} \mathrm{W}\right.$ and $\left.48-52^{\circ} \mathrm{N}\right)$ location away from urban areas; these two locations are displayed on the map in Fig. $5 b$ as inset numbers 1 and 2, respectively. We show aerosol surface area distributions for these two locations in Fig. 6c and $\mathrm{d}$ to demonstrate the distribution of SOA condensation. Generally, as the fraction of SOA increases, the number of particles decreases and the size distribution shifts to larger sizes. This is to be expected since the number of particles decreases while the mass remains relatively constant. In the Congo region, as OM dominates aerosol mass in the submicron mode $(83 \%)$ and ultrafine mode $(62 \%)$ in the 10SOA case, reducing primary emission of OM results in a decreased surface area below $\sim 500 \mathrm{~nm}$ diameter. We define the ultrafine surface fraction (USF) as the fraction of aerosol surface area in the ultrafine mode $\left(D_{\mathrm{p}}<0.1 \mu \mathrm{m}\right)$ with respect to the total surface; this represents the potential of SOA condensation to grow UF particles to $\mathrm{CCN}$ sizes. Figure $6 \mathrm{c}$ for the Congo 
a)

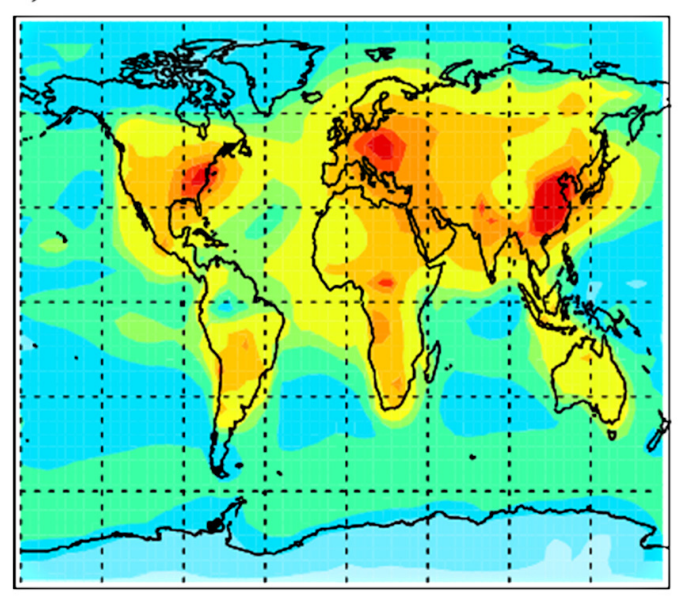

b)

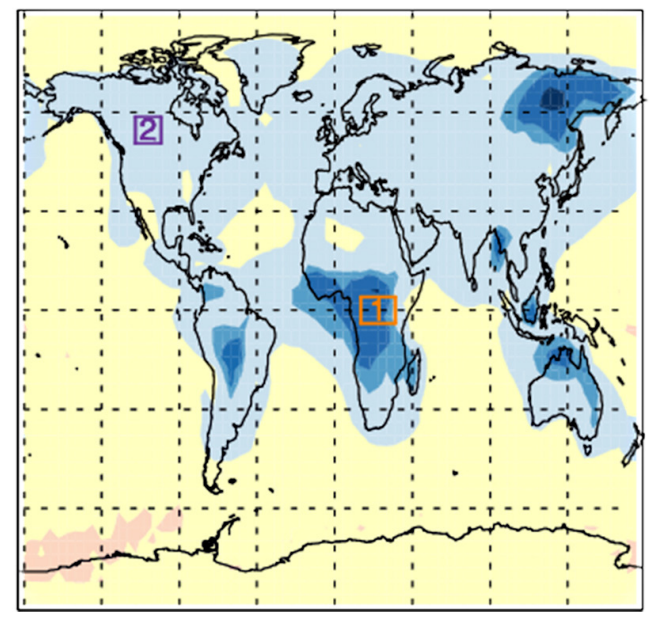

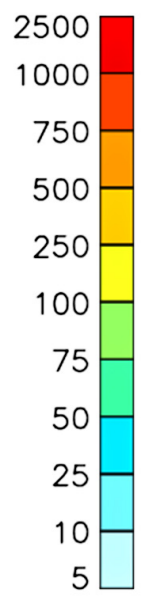

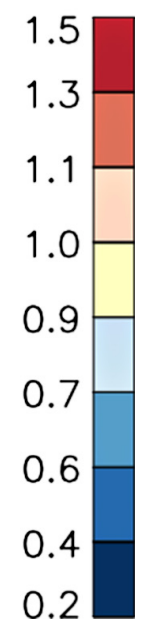

Fig. 5. (a) Predicted annual-average $\mathrm{CCN}(0.2 \%)$ concentrations $\left(\mathrm{cm}^{-3}\right.$ at $298 \mathrm{~K}$ and $\left.1 \mathrm{~atm}\right)$ in the surface layer for the 10SOA simulation; (b) Ratios of predicted annual-average surface $\mathrm{CCN}(0.2 \%)$ concentrations: (CCN 90SOA)/(CCN 10SOA). Boxes show the two regions (1: Congo and 2: North America) referred to in Fig. 6.

shows a reduction in USF from $11 \%$ in the 10SOA case to $6 \%$ in the 90SOA case. In other words, shifting the source of OM from POA to SOA in the Congo region not only lowers the emitted particle but also reduces the potential for ultrafine particles to grow via SOA and sulfate condensation. This location is admittedly an extreme case because the aerosol is dominated by organics and because POA is known to be a significant fraction of biomass burning aerosol.

More interesting is Fig. 6d, which shows a different environment in North America where sulfate is significant while OM mass only accounts for $30 \%$ of submicron and $33 \%$ ultrafine mode mass. The presence of primary sulfate or regional nucleation particles can be seen here because reducing primary organic emissions has a smaller effect than in the Congo. Also, the USF is reduced from $16 \%$ in the 10SOA case to $11 \%$ in the 90SOA case, which is a less drastic reduc- a)
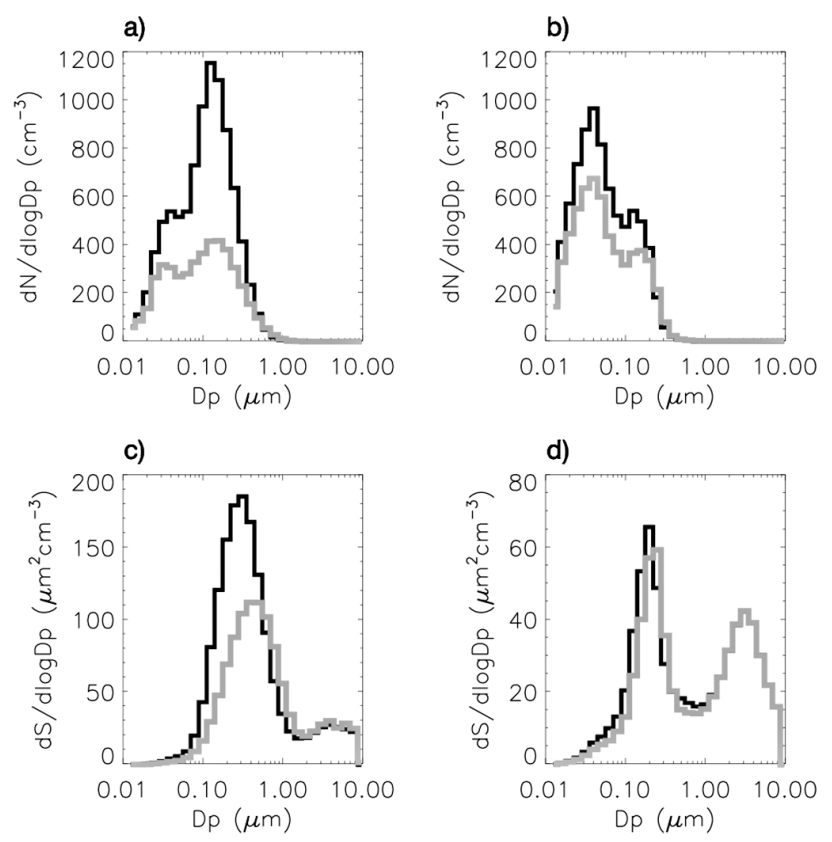

Fig. 6. Annual-average number size distributions for the surface layer of the (a) Congo $\left(12.5-32.5^{\circ} \mathrm{E}\right.$ and $\left.0-8^{\circ} \mathrm{S}\right)$ and (b) North American $\left(107.5-112.5^{\circ} \mathrm{W}\right.$ and $\left.48-52^{\circ} \mathrm{N}\right)$ regions, which are displayed as insets in Fig. 5b; annual-average surface area distribution for (c) Congo and (d) North America, respectively. The distributions from the 10SOA simulations are shown as black lines and those from the 90SOA simulations as grey lines.

tion compared to the Congo region. The lower overall contribution of OM mass as well as the compensating $\mathrm{CCN}$ via growth by SOA condensation explains the smaller reduction in number size distributions from 10SOA to 90SOA in the North America region in Fig. 6b, compared to the Congo in Fig. 6a.

\subsection{Effect on global CCN burdens}

In Fig. 7, we present the global-average $\mathrm{CCN}(0.2 \%)$ concentrations for different POA-SOA splits in the model surface layer and for the entire troposphere. The $\mathrm{CCN}(0.2 \%)$ concentrations from the NOCARB simulation are also shown for reference as horizontal dashed lines. To look at $\mathrm{CCN}(0.2 \%)$ contributed by carbonaceous aerosols, we take the difference between the prediction in a given simulation and the NOCARB CCN $(0.2 \%)$ concentration, and this is termed as $\triangle \mathrm{CCN}(0.2 \%)$. At the model surface layer, in the 0SOA run, $\Delta \mathrm{CCN}(0.2 \%)$ is $68 \mathrm{~cm}^{-3}$, whereas $\Delta \mathrm{CCN}(0.2 \%)$ is $33 \mathrm{~cm}^{-3}$ in the 100SOA run. Since the total OM source is constant and $\triangle \mathrm{CCN}(0.2 \%)$ in the $0 \mathrm{SOA}$ case is a factor of two higher than that from the 100SOA case, we can say that POA is about twice as effective at producing $\mathrm{CCN}(0.2 \%)$ per unit mass compared to SOA. We note here again that our relatively fast aging assumptions result in very similar 


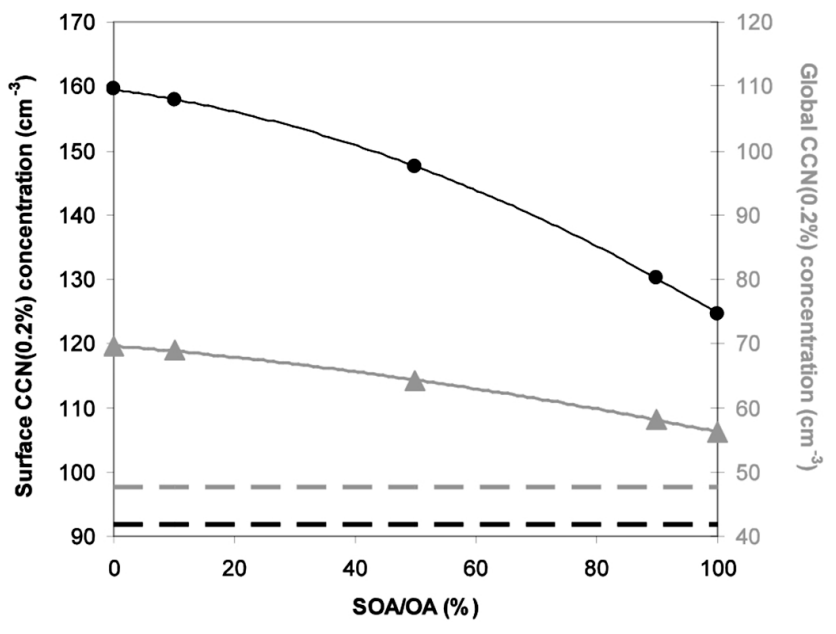

Fig. 7. Global-average $\mathrm{CCN}(0.2 \%)$ concentrations predicted in different POA-SOA sensitivity simulations for the model surface layer as well as the entire troposphere. The 10SOA run corresponds to the $10 \%$ SOA/OA point on the $x$ axis. Black circles and lines denote surface $\operatorname{CCN}(0.2 \%)$ concentrations with values displayed on the left vertical axis. Grey triangles and lines denote tropospheric average with values displayed on the right vertical axis. The corresponding $\mathrm{CCN}(0.2 \%)$ concentrations from the NOCARB simulation are also shown for reference as black and grey horizontal dashed lines.

OM hygroscopicity in both scenarios, so our results highlight the effects of microphysical pathways more than chemical composition. Doing a similar calculation on the global tropospheric $\mathrm{CCN}(0.2 \%)$ burden shows that POA is 2.5 times as effective at producing $\mathrm{CCN}(0.2 \%)$ per unit mass relative to SOA.

In terms of absolute concentrations, the reduction in surface $\mathrm{CCN}(0.2 \%)$ is from $160 \mathrm{~cm}^{-3}$ to $125 \mathrm{~cm}^{-3}$ for the OSOA and 100SOA case, respectively, which is about a $20 \%$ reduction. The reduction in the global tropospheric $\mathrm{CCN}(0.2 \%)$ burden is also approximately $20 \%$, going from 0 to $100 \%$ SOA/OA. The $20 \%$ change in global $\mathrm{CCN}(0.2 \%)$ concentration due to the change in microphysical path of $\mathrm{OA}$ formation is comparable to the influence of chemical composition/hygroscopicity. Pierce et al. (2007a) found a less than $20 \%$ reduction in global $\mathrm{CCN}(0.2 \%)$ when changing carbonaceous aerosols from a highly soluble scenario to a completely insoluble scenario.

Thus far, our discussion has focused on $\mathrm{CCN}$ at $0.2 \%$ supersaturation. At lower in-cloud supersaturations, $\mathrm{CCN}$ is limited to larger particles. In Fig. 6, we see that higher SOA fractions shift the size distribution to larger sizes, increasing the number of $\mathrm{CCN}$ active at lower supersaturations. These potentially "giant" cloud condensation nuclei (GCCN) may be important for cloud evolution and precipitation formation. We looked at the change in predicted $\mathrm{CCN}$ at different supersaturations down to $0.01 \%$ for different POA-SOA splits. We found that POA enhanced CCN concentrations at all supersaturations greater than $0.05 \%$, below which SOA is more effective at producing such "giant" CCN. However, even at very high SOA fractions (the 90SOA case), the enhancement in $\operatorname{CCN}(0.01 \%$ ) is still modest (within $4 \%$ ) compared to the 10SOA case, so we conclude that there is no strong impact of SOA on the formation of giant $\mathrm{CCN}$.

\section{Conclusions}

Carbonaceous aerosols, namely organic matter (OM) and black carbon (BC), have been implemented in the TOMAS microphysics module inside the global chemical transport model, GEOS-Chem. This version of TOMAS tracks aerosol, both number and mass, in 30 size sections covering the sizes from $10 \mathrm{~nm}$ to $10 \mu \mathrm{m}$. Hydrophobic OM, hydrophilic $\mathrm{OM}$, pure $\mathrm{BC}$ and mixed $\mathrm{BC}$ are tracked in the model. At this point, aerosol mass species in the model include sulfate, sea salt, BC and OM.

Contributions of carbonaceous aerosol to the $\mathrm{CN} 10$ and $\mathrm{CCN}(0.2 \%)$ predictions have been examined in comparison to a simulation with only sulfate and sea salt aerosols. In the model surface layer, CN10 increases localized around the carbonaceous source regions. With the introduction of carbonaceous aerosols, primary number emissions increase by a factor of 2.5 , and the annual-average global $\mathrm{CCN}(0.2 \%)$ burden increases by a factor of 2 . Inclusion of carbonaceous aerosols improves comparison of CN10 predictions to a set of long-term observations at various locations with a change from $45 \%$ underprediction on average to $7 \%$ underprediction on average. Similarly, inclusion of carbonaceous aerosols improves the $\mathrm{CCN}$ predictions when compared to observations. Whereas model predictions of $\mathrm{CCN}$ were biased low by a factor of 2.6 without carbonaceous aerosol, only a $20 \%$ low bias remains after inclusion of carbonaceous particles. The total source of OM in this model, 55 to $73 \mathrm{Tg} \mathrm{yr}^{-1}$ depending on the simulation, is low compared to more recent observationally driven estimates (Spracklen et al., 2011b; Heald et al., 2010). As a result, comparison of predicted EC and OC to measurements shows that the model underpredicts carbonaceous mass concentrations in the North American and European boundary layer by a factor of 2.1 (LMNB of -0.33), similar to several other "traditional" global models.

We performed simulations to assess the sensitivity of $\mathrm{CCN}$ production to the POA-SOA split by artificially shifting OM sources from primary POA emissions to SOA condensation while holding the total OM source constant. SOA and POA contribute to $\mathrm{CCN}$ via different microphysical pathways. Because the model assumes that rapid (1.15 days) aging of OM from hydrophobic to hydrophilic occurs, the overall $\mathrm{CCN}$ activity of OM in these simulations is quite similar, and differences primarily reflect the different microphysical pathways. The main finding is that $\mathrm{CCN}(0.2 \%)$ decreases nearly everywhere as the model changes from a POA-dominated world to a SOA-dominated world. This is because SOA condenses 
mostly onto the accumulation mode, thus not promoting any $\mathrm{CCN}(0.2 \%)$ growth. In contrast, POA emissions add significant numbers of particles, either directly to the $\mathrm{CCN}$ mode or to the ultrafine mode, a fraction of which grow to become $\mathrm{CCN}$. Not surprisingly, the reductions in $\mathrm{CCN}(0.2 \%)$ when shifting from POA to SOA are strongest in biomass burning regions, which are dominated by carbonaceous aerosol. In contrast, $\mathrm{CCN}(0.2 \%)$ reductions are less pronounced in locations with abundant inorganic ultrafine emissions because these provide condensational sink for SOA leading to $\mathrm{CCN}$ growth, which compensates for the missing POA.

We find that, compared to SOA, POA is about twice as effective per unit mass at $\mathrm{CCN}$ production at the model surface. By changing from completely POA to completely SOA, the $\mathrm{CCN}(0.2 \%)$ in the lowest model layer differ by about $20 \%$ compared to the values in the completely POA case. In contrast, Pierce et al. (2007b) found that global CCN $(0.2 \%)$ changed by less than $20 \%$ on average for a drastic change in assumed OM solubility (a change from highly active CCN to completely insoluble OM). We conclude that the SOAPOA split has a significant effect on global $\mathrm{CCN}$, and that the microphysical implications of POA versus SOA appear to be at least as important as differences in chemical composition. We conclude that carbonaceous aerosol overall makes a significant contribution to global $\mathrm{CCN}$; therefore, a better understanding of its total source will aid climate change simulations.

Acknowledgements. The authors acknowledge funding from the National Aeronautics and Space Administration (Award NNG04GE86G) and from The Office of the Civil Service Commission under The Royal Thai Government. We also appreciate that D. Spracklen and co-authors generously shared their compilation of CCN measurements.

Edited by: M. Kanakidou

\section{References}

Adams, P. J. and Seinfeld, J. H.: Predicting global aerosol size distributions in general circulation models, J. Geophys. Res.-Atmos., 107, AAC 4-1-AAC 4-23, doi:10.1029/2001JD001010, 2002.

Adams, P. J. and Seinfeld, J. H.: Disproportionate impact of particulate emissions on global cloud condensation nuclei concentrations, Geophys. Res. Lett., 30, 1239-1242, doi:10.1029/2002GL016303, 2003.

Albrecht, B. A.: Aerosols, Cloud Microphysics, and Fractional Cloudiness, Science, 245, 1227-1230, 1989.

Andreae, M. O., Elbert, W., and Demora, S. J.: Biogenic Sulfur Emissions and Aerosols over the Tropical South-Atlantic. 3. Atmospheric Dimethylsulfide, Aerosols and Cloud Condensation Nuclei, J. Geophys. Res.-Atmos., 100, 11335-11356, 1995.

Ban-Weiss, G. A., Lunden, M. M., Kirchstetter, T. W., and Harley, R. A.: Size-resolved particle number and volume emission factors for on-road gasoline and diesel motor vehicles, J. Aerosol Sci., 41, 5-12, 2010.
Bey, I., Jacob, D. J., Logan, J. A., and Yantosca, R. M.: Asian chemical outflow to the Pacific in spring: Origins, pathways, and budgets, J. Geophys. Res.-Atmos., 106, 23097-23113, 2001.

Bond, T. C. and Bergstrom, R. W.: Light absorption by carbonaceous particles: An investigative review, Aerosol Sci. Tech., 40, 27-67, 2006.

Bond, T. C., Streets, D. G., Yarber, K. F., Nelson, S. M., Woo, J. H., and Klimont, Z.: A technology-based global inventory of black and organic carbon emissions from combustion, J. Geophys. Res.-Atmos., 109, D14203, doi:10.1029/2003JD003697, 2004.

Cabada, J. C., Pandis, S. N., Subramanian, R., Robinson, A. L., Polidori, A., and Turpin, B.: Estimating the secondary organic aerosol contribution to $\mathrm{PM}_{2.5}$ using the EC tracer method, Aerosol Sci. Tech., 38, 140-155, 2004.

Chung, S. H. and Seinfeld, J. H.: Global distribution and climate forcing of carbonaceous aerosols, J. Geophys. Res.-Atmos., 107, AAC 14-1-AAC 14-33, doi:10.1029/2001JD001397, 2002.

Clarke, A. D., Ahlquist, N. C., and Covert, D. S.: The Pacific Marine Aerosol - Evidence for Natural Acid Sulfates, J. Geophys. Res.Atmos., 92, 4179-4190, 1987.

Cooke, W. F., Liousse, C., Cachier, H., and Feichter, J.: Construction of a 1 degrees $\mathrm{x} 1$ degrees fossil fuel emission data set for carbonaceous aerosol and implementation and radiative impact in the ECHAM4 model, J. Geophys. Res.-Atmos., 104, 2213722162, 1999.

Covert, D. S., Kapustin, V. N., Bates, T. S., and Quinn, P. K.: Physical properties of marine boundary layer aerosol particles of the mid-Pacific in relation to sources and meteorological transport, J. Geophys. Res.-Atmos., 101, 6919-6930, 1996.

de Gouw, J. A., Middlebrook, A. M., Warneke, C., Goldan, P. D., Kuster, W. C., Roberts, J. M., Fehsenfeld, F. C., Worsnop, D. R., Canagaratna, M. R., Pszenny, A. A. P., Keene, W. C., Marchewka, M., Bertman, S. B., and Bates, T. S.: Budget of organic carbon in a polluted atmosphere: Results from the New England Air Quality Study in 2002, J. Geophys. Res.-Atmos., 110, D16305, doi:10.1029/2004JD005623, 2005.

El-Zanan, H. S., Lowenthal, D. H., Zielinska, B., Chow, J. C., and Kumar, N.: Determination of the organic aerosol mass to organic carbon ratio in IMPROVE samples, Chemosphere, 60, 485-496, 2005.

Farina, S. C., Adams, P. J., and Pandis, S. N.: Modeling global secondary organic aerosol formation and processing with the volatility basis set: Implications for anthropogenic secondary organic aerosol, J. Geophys. Res.-Atmos., 115, D09202, doi:10.1029/2009JD013046, 2010.

Fitzgerald, J. W.: Marine Aerosols - a Review, Atmos. Environ. AGen., 25, 533-545, 1991.

Giglio, L., van der Werf, G. R., Randerson, J. T., Collatz, G. J., and Kasibhatla, P.: Global estimation of burned area using MODIS active fire observations, Atmos. Chem. Phys., 6, 957974, doi:10.5194/acp-6-957-2006, 2006.

Griffin, R. J., Cocker, D. R., Seinfeld, J. H., and Dabdub, D.: Estimate of global atmospheric organic aerosol from oxidation of biogenic hydrocarbons, Geophys. Res. Lett., 26, 2721-2724, doi:10.1029/1999g1900476, 1999.

Guenther, A., Karl, T., Harley, P., Wiedinmyer, C., Palmer, P. I., and Geron, C.: Estimates of global terrestrial isoprene emissions using MEGAN (Model of Emissions of Gases and Aerosols from 
Nature), Atmos. Chem. Phys., 6, 3181-3210, doi:10.5194/acp-63181-2006, 2006.

Gunthe, S. S., King, S. M., Rose, D., Chen, Q., Roldin, P., Farmer, D. K., Jimenez, J. L., Artaxo, P., Andreae, M. O., Martin, S. T., and Pöschl, U.: Cloud condensation nuclei in pristine tropical rainforest air of Amazonia: size-resolved measurements and modeling of atmospheric aerosol composition and CCN activity, Atmos. Chem. Phys., 9, 7551-7575, doi:10.5194/acp-9-75512009, 2009.

Hallquist, M., Wenger, J. C., Baltensperger, U., Rudich, Y., Simpson, D., Claeys, M., Dommen, J., Donahue, N. M., George, C., Goldstein, A. H., Hamilton, J. F., Herrmann, H., Hoffmann, T., Iinuma, Y., Jang, M., Jenkin, M. E., Jimenez, J. L., Kiendler-Scharr, A., Maenhaut, W., McFiggans, G., Mentel, Th. F., Monod, A., Prévôt, A. S. H., Seinfeld, J. H., Surratt, J. D., Szmigielski, R., and Wildt, J.: The formation, properties and impact of secondary organic aerosol: current and emerging issues, Atmos. Chem. Phys., 9, 5155-5236, doi:10.5194/acp-9-51552009, 2009.

Hanel, G.: Single-Scattering Albedo of Atmospheric AerosolParticles as a Function of Relative Humidity, J. Atmos. Sci., 33, 1120-1124, 1976.

Heald, C. L., Jacob, D. J., Park, R. J., Russell, L. M., Huebert, B. J., Seinfeld, J. H., Liao, H., and Weber, R. J.: A large organic aerosol source in the free troposphere missing from current models, Geophys. Res. Lett., 32, L18809, doi:10.1029/2005GL023831, 2005.

Heald, C. L., Jacob, D. J., Turquety, S., Hudman, R. C., Weber, R. J., Sullivan, A. P., Peltier, R. E., Atlas, E. L., de Gouw, J. A., Warneke, C., Holloway, J. S., Neuman, J. A., Flocke, F. M., and Seinfeld, J. H.: Concentrations and sources of organic carbon aerosols in the free troposphere over North America, J. Geophys. Res.-Atmos., 111, D23S47, doi:10.1029/2006JD007705, 2006.

Heald, C. L., Ridley, D. A., Kreidenweis, S. M., and Drury, E. E.: Satellite observations cap the atmospheric organic aerosol budget, Geophys. Res. Lett., 37, L24808, doi:10.1029/2010GL045095, 2010.

Heald, C. L., Coe, H., Jimenez, J. L., Weber, R. J., Bahreini, R., Middlebrook, A. M., Russell, L. M., Jolleys, M., Fu, T.-M., Allan, J. D., Bower, K. N., Capes, G., Crosier, J., Morgan, W. T., Robinson, N. H., Williams, P. I., Cubison, M. J., DeCarlo, P. F., and Dunlea, E. J.: Exploring the vertical profile of atmospheric organic aerosol: comparing 17 aircraft field campaigns with a global model, Atmos. Chem. Phys., 11, 12673-12696, doi:10.5194/acp-11-12673-2011, 2011.

Hitzenberger, R., Berner, A., Giebl, H., Kromp, R., Larson, S. M., Rouc, A., Koch, A., Marischka, S., and Puxbaum, H.: Contribution of carbonaceous material to cloud condensation nuclei concentrations in European background (Mt. Sonnblick) and urban (Vienna) aerosols, Atmos. Environ., 33, 2647-2659, 1999.

IMPROVE: IMPROVE Data Guide - A GUIDE TO INTERPRET DATA, University of California Davis, 1995.

IPCC: Intergovernmental Panel on Climate Change, Climate Change 2007: The Physical Science Basis. Summary for Policymakers, Cambridge Univ. Press, New York, 2007.

Jathar, S. H., Farina, S. C., Robinson, A. L., and Adams, P. J.: The influence of semi-volatile and reactive primary emissions on the abundance and properties of global organic aerosol, Atmos. Chem. Phys., 11, 7727-7746, doi:10.5194/acp-11-77272011, 2011.
Johnson, D., Utembe, S. R., Jenkin, M. E., Derwent, R. G., Hayman, G. D., Alfarra, M. R., Coe, H., and McFiggans, G.: Simulating regional scale secondary organic aerosol formation during the TORCH 2003 campaign in the southern UK, Atmos. Chem. Phys., 6, 403-418, doi:10.5194/acp-6-403-2006, 2006.

Kanakidou, M., Tsigaridis, K., Dentener, F. J., and Crutzen, P. J.: Human-activity-enhanced formation of organic aerosols by biogenic hydrocarbon oxidation, J. Geophys. Res.-Atmos., 105, 9243-9254, 2000.

Kanakidou, M., Seinfeld, J. H., Pandis, S. N., Barnes, I., Dentener, F. J., Facchini, M. C., Van Dingenen, R., Ervens, B., Nenes, A., Nielsen, C. J., Swietlicki, E., Putaud, J. P., Balkanski, Y., Fuzzi, S., Horth, J., Moortgat, G. K., Winterhalter, R., Myhre, C. E. L., Tsigaridis, K., Vignati, E., Stephanou, E. G., and Wilson, J.: Organic aerosol and global climate modelling: a review, Atmos. Chem. Phys., 5, 1053-1123, doi:10.5194/acp-5-1053-2005, 2005.

Kerminen, V. M.: The effects of particle chemical character and atmospheric processes on particle hygroscopic properties, J. Aerosol Sci., 28, 121-132, 1997.

Koch, D., Jacob, D., Tegen, I., Rind, D., and Chin, M.: Tropospheric sulfur simulation and sulfate direct radiative forcing in the Goddard Institute for Space Studies general circulation model, J. Geophys. Res.-Atmos., 104, 23799-23822, 1999.

Kondo, Y., Miyazaki, Y., Takegawa, N., Miyakawa, T., Weber, R. J., Jimenez, J. L., Zhang, Q., and Worsnop, D. R.: Oxygenated and water-soluble organic aerosols in Tokyo, J. Geophys. Res.Atmos., 112, D01203, doi:10.1029/2006JD007056, 2007.

Kumagai, K., Iijima, A., Tago, H., Tomioka, A., Kozawa, K., and Sakamoto, K.: Seasonal characteristics of water-soluble organic carbon in atmospheric particles in the inland Kanto plain, Japan, Atmos. Environ., 43, 3345-3351, 2009.

Laaksonen, A., Korhonen, P., Kulmala, M., and Charlson, R. J.: Modification of the Kuhler equation to include soluble trace gases and slightly soluble substances, J. Atmos. Sci., 55, 853862, 1998.

Lamarque, J. F., Kyle, G. P., Meinshausen, M., Riahi, K., Smith, S. J., van Vuuren, D. P., Conley, A. J., and Vitt, F.: Global and regional evolution of short-lived radiatively-active gases and aerosols in the Representative Concentration Pathways, Clim. Change, 109, 191-212, doi:10.1007/s10584-011-0155-0, 2011.

Lin, S. J. and Rood, R. B.: Multidimensional flux-form semiLagrangian transport schemes, Mon. Weather Rev., 124, 20462070, 1996.

Liousse, C., Penner, J. E., Chuang, C., Walton, J. J., Eddleman, H., and Cachier, H.: A global three-dimensional model study of carbonaceous aerosols, J. Geophys. Res.-Atmos., 101, 1941119432, 1996.

Merikanto, J., Spracklen, D. V., Mann, G. W., Pickering, S. J., and Carslaw, K. S.: Impact of nucleation on global CCN, Atmos. Chem. Phys., 9, 8601-8616, doi:10.5194/acp-9-8601-2009, 2009.

Pandis, S. N., Wexler, A. S., and Seinfeld, J. H.: Dynamics of Tropospheric Aerosols, J. Phys. Chem., 99, 9646-9659, 1995.

Park, R. J., Jacob, D. J., Chin, M., and Martin, R. V.: Sources of carbonaceous aerosols over the United States and implications for natural visibility, J. Geophys. Res.-Atmos., 108, 4355, doi:10.1029/2002JD003190, 2003. 
Park, R. J., Jacob, D. J., Palmer, P. I., Clarke, A. D., Weber, R. J., Zondlo, M. A., Eisele, F. L., Bandy, A. R., Thornton, D. C., Sachse, G. W., and Bond, T. C.: Export efficiency of black carbon aerosol in continental outflow: Global implications, J. Geophys. Res.-Atmos., 110, D11205, doi:10.1029/2004jd005432, 2005.

Park, R. J., Jacob, D. J., Kumar, N., and Yantosca, R. M.: Regional visibility statistics in the United States: Natural and transboundary pollution influences, and implications for the Regional Haze Rule, Atmos. Environ., 40, 5405-5423, 2006.

Petters, M. D. and Kreidenweis, S. M.: A single parameter representation of hygroscopic growth and cloud condensation nucleus activity, Atmos. Chem. Phys., 7, 1961-1971, doi:10.5194/acp-71961-2007, 2007.

Pierce, J. R. and Adams, P. J.: Efficiency of cloud condensation nuclei formation from ultrafine particles, Atmos. Chem. Phys., 7, 1367-1379, doi:10.5194/acp-7-1367-2007, 2007.

Pierce, J. R. and Adams, P. J.: Uncertainty in global CCN concentrations from uncertain aerosol nucleation and primary emission rates, Atmos. Chem. Phys., 9, 1339-1356, doi:10.5194/acp-91339-2009, 2009.

Pierce, J. R., Chen, K., and Adams, P. J.: Contribution of primary carbonaceous aerosol to cloud condensation nuclei: processes and uncertainties evaluated with a global aerosol microphysics model, Atmos. Chem. Phys., 7, 5447-5466, doi:10.5194/acp-75447-2007, 2007a.

Pierce, J. R., Chen, K., and Adams, P. J.: Contribution of primary carbonaceous aerosol to cloud condensation nuclei: processes and uncertainties evaluated with a global aerosol microphysics model, Atmos. Chem. Phys., 7, 5447-5466, doi:10.5194/acp-75447-2007, 2007b.

Pierce, J. R., Theodoritsi, G., Adams, P. J., and Pandis, S. N.: Parameterization of the effect of sub-grid scale aerosol dynamics on aerosol number emission rates, J. Aerosol Sci., 40, 385-393, doi:10.1016/j.jaerosci.2008.11.009, 2009.

Pun, B. K., Wu, S. Y., Seigneur, C., Seinfeld, J. H., Griffin, R. J., and Pandis, S. N.: Uncertainties in modeling secondary organic aerosols: Three-dimensional modeling studies in Nashville/Western Tennessee, Environ. Sci. Technol., 37, 36473661, 2003.

Putaud, J. P., Raes, F., Van Dingenen, R., Bruggemann, E., Facchini, M. C., Decesari, S., Fuzzi, S., Gehrig, R., Huglin, C., Laj, P., Lorbeer, G., Maenhaut, W., Mihalopoulos, N., Mulller, K., Querol, X., Rodriguez, S., Schneider, J., Spindler, G., ten Brink, H., Torseth, K., and Wiedensohler, A.: European aerosol phenomenology-2: chemical characteristics of particulate matter at kerbside, urban, rural and background sites in Europe, Atmos. Environ., 38, 2579-2595, 2004.

Pye, H. O. T. and Seinfeld, J. H.: A global perspective on aerosol from low-volatility organic compounds, Atmos. Chem. Phys., 10, 4377-4401, doi:10.5194/acp-10-4377-2010, 2010.

Raes, F., Van Dingenen, R., Vignati, E., Wilson, J., Putaud, J. P., Seinfeld, J. H., and Adams, P.: Formation and cycling of aerosols in the global troposphere, Atmos. Environ., 34, 42154240, doi:10.1016/s1352-2310(00)00239-9, 2000.

Raymond, T. M. and Pandis, S. N.: Cloud activation of singlecomponent organic aerosol particles, J. Geophys. Res.-Atmos., 107, 4787, doi:10.1029/2002JD002159, 2002.
Raymond, T. M. and Pandis, S. N.: Formation of cloud droplets by multicomponent organic particles, J. Geophys. Res.-Atmos., 108, 4469, doi:10.1029/2003JD003503, 2003.

Reddington, C. L., Carslaw, K. S., Spracklen, D. V., Frontoso, M. G., Collins, L., Merikanto, J., Minikin, A., Hamburger, T., Coe, H., Kulmala, M., Aalto, P., Flentje, H., Plass-Dülmer, C., Birmili, W., Wiedensohler, A., Wehner, B., Tuch, T., Sonntag, A., O'Dowd, C. D., Jennings, S. G., Dupuy, R., Baltensperger, U., Weingartner, E., Hansson, H.-C., Tunved, P., Laj, P., Sellegri, K., Boulon, J., Putaud, J.-P., Gruening, C., Swietlicki, E., Roldin, P., Henzing, J. S., Moerman, M., Mihalopoulos, N., Kouvarakis, G., Ždímal, V., Zíková, N., Marinoni, A., Bonasoni, P., and Duchi, R.: Primary versus secondary contributions to particle number concentrations in the European boundary layer, Atmos. Chem. Phys., 11, 12007-12036, doi:10.5194/acp-11-12007-2011, 2011.

Riipinen, I., Pierce, J. R., Yli-Juuti, T., Nieminen, T., Häkkinen, S., Ehn, M., Junninen, H., Lehtipalo, K., Petäjä, T., Slowik, J., Chang, R., Shantz, N. C., Abbatt, J., Leaitch, W. R., Kerminen, V.-M., Worsnop, D. R., Pandis, S. N., Donahue, N. M., and Kulmala, M.: Organic condensation: a vital link connecting aerosol formation to cloud condensation nuclei (CCN) concentrations, Atmos. Chem. Phys., 11, 3865-3878, doi:10.5194/acp-11-38652011, 2011.

Robinson, A. L., Donahue, N. M., Shrivastava, M. K., Weitkamp, E. A., Sage, A. M., Grieshop, A. P., Lane, T. E., Pierce, J. R., and Pandis, S. N.: Rethinking organic aerosols: Semivolatile emissions and photochemical aging, Science, 315, 1259-1262, 2007.

Saxena, P. and Hildemann, L. M.: Water-soluble organics in atmospheric particles: A critical review of the literature and application of thermodynamics to identify candidate compounds, J. Atmos. Chem., 24, 57-109, 1996.

Schnell, R. C.: Chapter 3: Aerosols and Radiation, in: Climate Monitoring and Diagnostics Laboratory Summary Report, edited by: McComisky, A., 2002-2003, 2003.

Seinfeld, J. H. and Pandis, S. N.: Atmospheric Chemistry and Physics: From Air Pollution to Climate Change, John Wiley \& Sons, New York, 1998.

Seinfeld, J. H., Erdakos, G. B., Asher, W. E., and Pankow, J. F.: Modeling the formation of secondary organic aerosol (SOA). 2. The predicted effects of relative humidity on aerosol formation in the alpha-pinene-, beta-pinene-, sabinene-, Delta(3)-carene-, and cyclohexene-ozone systems (vol 35, pg 1806, 2001), Environ. Sci. Technol., 35, p. 3272, 2001.

Shrivastava, M. K., Subramanian, R., Rogge, W. F., and Robinson, A. L.: Sources of organic aerosol: Positive matrix factorization of molecular marker data and comparison of results from different source apportionment models, Atmos. Environ., 41, 9353-9369, 2007.

Spracklen, D. V., Carslaw, K. S., Pöschl, U., Rap, A., and Forster, P. M.: Global cloud condensation nuclei influenced by carbonaceous combustion aerosol, Atmos. Chem. Phys., 11, 9067-9087, doi:10.5194/acp-11-9067-2011, 2011a.

Spracklen, D. V., Jimenez, J. L., Carslaw, K. S., Worsnop, D. R., Evans, M. J., Mann, G. W., Zhang, Q., Canagaratna, M. R., Allan, J., Coe, H., McFiggans, G., Rap, A., and Forster, P.: Aerosol mass spectrometer constraint on the global secondary organic aerosol budget, Atmos. Chem. Phys., 11, 12109-12136, doi:10.5194/acp-11-12109-2011, $2011 \mathrm{~b}$. 
Subramanian, R., Donahue, N. M., Bernardo-Bricker, A., Rogge, W. F., and Robinson, A. L.: Insights into the primary-secondary and regional-local contributions to organic aerosol and PM2.5 mass in Pittsburgh, Pennsylvania, Atmos. Environ., 41, 74147433, 2007.

Suda, S. R., Petters, M. D., Matsunaga, A., Sullivan, R. C., Ziemann, P. J., and Kreidenweis, S. M.: Hygroscopicity frequency distributions of secondary organic aerosols, J. Geophys. Res.Atmos., 117, D04207, doi:10.1029/2011jd016823, 2012.

Trivitayanurak, W., Adams, P. J., Spracklen, D. V., and Carslaw, K. S.: Tropospheric aerosol microphysics simulation with assimilated meteorology: model description and intermodel comparison, Atmos. Chem. Phys., 8, 3149-3168, doi:10.5194/acp-83149-2008, 2008.

Tsigaridis, K. and Kanakidou, M.: Global modelling of secondary organic aerosol in the troposphere: a sensitivity analysis, Atmos. Chem. Phys., 3, 1849-1869, doi:10.5194/acp-3-1849-2003, 2003.

Twomey, S.: Pollution and Planetary Albedo, Atmos. Environ., 8, 1251-1256, 1974.

van der Werf, G. R., Randerson, J. T., Giglio, L., Collatz, G. J., Kasibhatla, P. S., and Arellano Jr., A. F.: Interannual variability in global biomass burning emissions from 1997 to 2004, Atmos. Chem. Phys., 6, 3423-3441, doi:10.5194/acp-6-3423-2006, 2006.

Van Dingenen, R., Raes, F., Putaud, J. P., Baltensperger, U., Charron, A., Facchini, M. C., Decesari, S., Fuzzi, S., Gehrig, R., Hansson, H. C., Harrison, R. M., Huglin, C., Jones, A. M., Laj, P., Lorbeer, G., Maenhaut, W., Palmgren, F., Querol, X., Rodriguez, S., Schneider, J., ten Brink, H., Tunved, P., Torseth, K., Wehner, B., Weingartner, E., Wiedensohler, A., and Wahlin, P.: A European aerosol phenomenology-1: physical characteristics of particulate matter at kerbside, urban, rural and background sites in Europe, Atmos. Environ., 38, 2561-2577, 2004.

Volkamer, R., Jimenez, J. L., San Martini, F., Dzepina, K., Zhang, Q., Salcedo, D., Molina, L. T., Worsnop, D. R., and Molina, M. J.: Secondary organic aerosol formation from anthropogenic air pollution: Rapid and higher than expected, Geophys. Res. Lett., 33, L17811, doi:10.1029/2006GL026899, 2006.
Vutukuru, S., Griffin, R. J., and Dabdub, D.: Simulation and analysis of secondary organic aerosol dynamics in the South Coast Air Basin of California, J. Geophys. Res.-Atmos., 111, D10S12, doi:10.1029/2005JD006139, 2006.

Wexler, A. S., Lurmann, F. W., and Seinfeld, J. H.: Modelling urban and regional aerosols - I. Modeling development, Atmos. Environ., 28, 531-546, 1994.

Yu, L. E., Shulman, M. L., Kopperud, R., and Hildemann, L. M.: Fine organic aerosols collected in a humid, rural location (Great Smoky Mountains, Tennessee, USA): Chemical and temporal characteristics, Atmos. Environ., 39, 6037-6050, 2005.

Zhang, K., O’Donnell, D., Kazil, J., Stier, P., Kinne, S., Lohmann, U., Ferrachat, S., Croft, B., Quaas, J., Wan, H., Rast, S., and Feichter, J.: The global aerosol-climate model ECHAM-HAM, version 2: sensitivity to improvements in process representations, Atmos. Chem. Phys., 12, 8911-8949, doi:10.5194/acp-12-89112012, 2012.

Zhang, L. M., Gong, S. L., Padro, J., and Barrie, L.: A sizesegregated particle dry deposition scheme for an atmospheric aerosol module, Atmos. Environ., 35, 549-560, 2001.

Zhang, Q., Worsnop, D. R., Canagaratna, M. R., and Jimenez, J. L.: Hydrocarbon-like and oxygenated organic aerosols in Pittsburgh: insights into sources and processes of organic aerosols, Atmos. Chem. Phys., 5, 3289-3311, doi:10.5194/acp-5-32892005, 2005.

Zhang, Q., Jimenez, J. L., Canagaratna, M. R., Allan, J. D., Coe, H., Ulbrich, I., Alfarra, M. R., Takami, A., Middlebrook, A. M., Sun, Y. L., Dzepina, K., Dunlea, E., Docherty, K., DeCarlo, P. F., Salcedo, D., Onasch, T., Jayne, J. T., Miyoshi, T., Shimono, A., Hatakeyama, S., Takegawa, N., Kondo, Y., Schneider, J., Drewnick, F., Borrmann, S., Weimer, S., Demerjian, K., Williams, P., Bower, K., Bahreini, R., Cottrell, L., Griffin, R. J., Rautiainen, J., Sun, J. Y., Zhang, Y. M., and Worsnop, D. R.: Ubiquity and dominance of oxygenated species in organic aerosols in anthropogenically-influenced Northern hemisphere midlatitudes, Geophys. Res. Lett., 34, L13801, doi:10.1029/2007GL029979, 2007. 